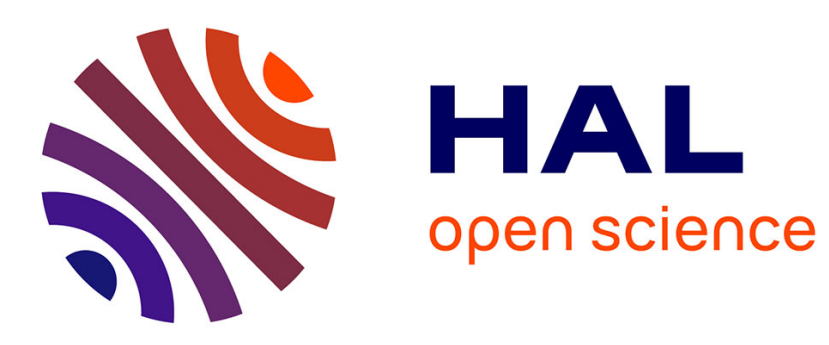

\title{
A strong-motion database from the Peru-Chile subduction zone
}

Maria C. Arango, Fleur O. Strasser, Julian J. Bommer, Ruben Boroschek, Diana Comte, Hernando Tavera

\section{- To cite this version:}

Maria C. Arango, Fleur O. Strasser, Julian J. Bommer, Ruben Boroschek, Diana Comte, et al.. A strong-motion database from the Peru-Chile subduction zone. Journal of Seismology, 2010, 15 (1), pp.19-41. 10.1007/s10950-010-9203-x . hal-00616251

\section{HAL Id: hal-00616251 \\ https://hal.science/hal-00616251}

Submitted on 21 Aug 2011

HAL is a multi-disciplinary open access archive for the deposit and dissemination of scientific research documents, whether they are published or not. The documents may come from teaching and research institutions in France or abroad, or from public or private research centers.
L'archive ouverte pluridisciplinaire HAL, est destinée au dépôt et à la diffusion de documents scientifiques de niveau recherche, publiés ou non, émanant des établissements d'enseignement et de recherche français ou étrangers, des laboratoires publics ou privés. 


\section{Editorial Manager(tm) for Journal of Seismology}

Manuscript Draft

Manuscript Number: JOSE451R1

Title: A Strong-Motion Database from the Peru-Chile Subduction Zone

Article Type: Manuscript

Keywords: Peru-Chile subduction zone; strong-motion database; ground-motion processing; site classes; source and path parameters.

Corresponding Author: Dr. Julian J Bommer, PhD MSc

Corresponding Author's Institution: Imperial College London

First Author: Maria C Arango, PhD

Order of Authors: Maria C Arango, PhD; Fleur O Strasser, PhD; Julian J Bommer, PhD MSc; Ruben Boroscheck, PhD; Diana Comte, PhD; Hernando Tavera, PhD

Abstract: Earthquake hazard along the Peru-Chile subduction zone is amongst the highest in the world. The development of a database of subduction-zone strong-motion recordings is therefore of great importance for ground-motion prediction in this region. Accelerograms recorded by the different networks operators in Peru and Chile have been compiled and processed in a uniform manner and information on the source parameters of the causative earthquakes, fault-plane geometries and local site conditions at the recording stations has been collected and reviewed to obtain high-quality metadata. The compiled database consists of 98 triaxial ground-motion recordings from 15 subduction-type events with moment magnitudes ranging from 6.3 to 8.4, recorded at 55 different sites in Peru and Chile, between 1966 and 2007. While the database presented in this study is not sufficient for the derivation of a new predictive equation for ground motions from subduction events in the Peru-Chile region, it significantly expands the global database of strong-motion data and associated metadata that can be used in the derivation of predictive equations for subduction environments. Additionally, the compiled database will allow the assessment of the existing predictive models for subduction-type events in terms of their suitability for the Peru-Chile region, which directly influences seismic hazard assessment in this region.

Response to Reviewers:

We are grateful to the responsible editor and to the two anonymous reviews for the timely and constructive feedback on our paper. In this document, we explain how we have responded to each of the comments from the reviewers.

\section{Reviewer \#1}

This is a very comprehensive and useful compilation of metadata. The various heterogeneous characteristics of the metadata are handled well

We are very grateful for these constructive comments and encouraged by the endorsement of the value of the paper in presenting this dataset to the seismological and engineering communities. 


\section{Reviewer \#2}

Overall, the paper presents an important contribution to the earthquake hazard community and should be published with minor revisions.

We are grateful for and encouraged by this endorsement of our manuscript.

My main comments are:

1. There is no mention in the paper of the availability of the assembled database. The paper should indicate if the intention is for the database to be available to the interested user and if so, how it may be accessed. Publication of the paper without this information would seem to be a disservice.

This point is very well taken and we realise that the paper would fall short of its objectives if it did not indicate the availability of the dataset. Therefore, we have added a column to Table 1 in which we indicate the source from where the records may be accessed, which in some cases is by request to the 4th and 6th authors who manage strong-motion networks in Chile and Peru respectively.

2. The paragraph starting on line 14 of page 7 seems to indicate that focal mechanism data are presented in Table 1, but this data is not present in the table.

This is another valuable suggestion, which we have responded to by adding this information to Table 1 .

3. With regard to Table 1, the useful metadata is incomplete. I suggest that the authors add the following information: epicenter location, dip of the selected fault model, top and bottom depths of the selected fault model used to compute rupture distances, mechanism (see comment 2).

All of this information has also been added to Table 1, as suggested by the reviewer.

\section{Minor comments:}

There are a few acronyms used without definition (e.g. PGA). Although their meaning is generally clear, they should be defined.

We agree with this comment and have added definitions for acronyms where they first appear in the text.

The paper needs some editorial review, there are a number of miss-spellings (e.g. storeys) and Table 2 is labeled as Table 3.

The labelling of Table 2 has been corrected and the paper has been carefully proof-read in order to correct a few errors, but with regards to the specific example given (storeys) we have used UK rather than US English throughout the paper. Since this is a European rather than North American journal, we believe that the use of UK English is acceptable. 


\section{Manuscript JOSE451}

\section{"A Strong-Motion Database from the Peru-Chile Subduction Zone"

\author{
M.C. Arango, F.O. Strasser, J.J. Bommer, R. Boroschek, D. Comté \& H. Tavera
}

\section{Authors' Responses to Review Comments}

We are grateful to the responsible editor and to the two anonymous reviews for the timely and constructive feedback on our paper. In this document, we explain how we have responded to each of the comments from the reviewers, using different fonts to distinguish the review comments (italic Times New Roman) from our response (Arial).

\section{Reviewer \#1}

This is a very comprehensive and useful compilation of metadata. The various heterogeneous characteristics of the metadata are handled well

We are very grateful for these constructive comments and encouraged by the endorsement of the value of the paper in presenting this dataset to the seismological and engineering communities.

\section{Reviewer \#2}

Overall, the paper presents an important contribution to the earthquake hazard community and should be published with minor revisions.

We are grateful for and encouraged by this endorsement of our manuscript.

My main comments are:

1. There is no mention in the paper of the availability of the assembled database. The paper should indicate if the intention is for the database to be available to the interested user and if so, how it may be accessed. Publication of the paper without this information would seem to be a disservice. 
This point is very well taken and we realise that the paper would fall short of its objectives if it did not indicate the availability of the dataset. Therefore, we have added a column to Table 1 in which we indicate the source from where the records may be accessed, which in some cases is by request to the $4^{\text {th }}$ and $6^{\text {th }}$ authors who manage strong-motion networks in Chile and Peru respectively.

2. The paragraph starting on line 14 of page 7 seems to indicate that focal mechanism data are presented in Table 1, but this data is not present in the table.

This is another valuable suggestion, which we have responded to by adding this information to Table 1.

3. With regard to Table 1, the useful metadata is incomplete. I suggest that the authors add the following information: epicenter location, dip of the selected fault model, top and bottom depths of the selected fault model used to compute rupture distances, mechanism (see comment 2).

All of this information has also been added to Table 1, as suggested by the reviewer.

Minor comments:

There are a few acronyms used without definition (e.g. PGA). Although their meaning is generally clear, they should be defined.

We agree with this comment and have added definitions for acronyms where they first appear in the text.

The paper needs some editorial review, there are a number of miss-spellings (e.g. storeys) and Table 2 is labeled as Table 3.

The labelling of Table 2 has been corrected and the paper has been carefully proof-read in order to correct a few errors, but with regards to the specific example given (storeys) we have used UK rather than US English throughout the paper. Since this is a European rather than North American journal, we believe that the use of UK English is acceptable. 


\title{
A STRONG-MOTION DATABASE FROM THE PERU-CHILE SUBDUCTION ZONE
}

\author{
M.C. Arango ${ }^{1}$, F.O. Strasser ${ }^{2}$, J.J. Bommer ${ }^{1 *}$, R. Boroschek ${ }^{3}$, D. Comté ${ }^{4}$ \& H. Tavera $^{5}$ \\ 1. Department of Civil \& Environmental Engineering, Imperial College London, London SW7 2AZ, UK \\ 2. Seismology Unit, Council for Geoscience, Private Bag X112, Pretoria 0001, South Africa \\ 3. Department of Civil Engineering, University of Chile, Blanco Encalada 2002, Santiago, Chile \\ 4. Department of Geophysics, University of Chile, Blanco Encalada 2002, Santiago, Chile \\ 5. Seismology department, Geophysical Institute of Peru, Calle Badajoz 169, Urb Mayorazgo IV Etapa, Ate, Lima, Peru
}

\begin{abstract}
Earthquake hazard along the Peru-Chile subduction zone is amongst the highest in the world. The development of a database of subduction-zone strong motion recordings is therefore of great importance for ground-motion prediction in this region. Accelerograms recorded by the different networks operators in Peru and Chile have been compiled and processed in a uniform manner and information on the source parameters of the causative earthquakes, fault-plane geometries and local site conditions at the recording stations has been collected and reviewed to obtain highquality metadata. The compiled database consists of 98 triaxial ground-motion recordings from 15 subduction-type events with moment magnitudes ranging from 6.3 to 8.4 , recorded at 55 different sites in Peru and Chile, between 1966 and 2007. While the database presented in this study is not sufficient for the derivation of a new predictive equation for ground motions from subduction events in the Peru-Chile region, it significantly expands the global database of strong-motion data and associated metadata that can be used in the derivation of predictive equations for subduction environments. Additionally, the compiled database will allow the assessment of the existing predictive models for subduction-type events in terms of their suitability for the Peru-Chile region, which directly influences seismic hazard assessment in this region.
\end{abstract}

Keywords: Peru-Chile subduction zone, strong-motion database, ground-motion processing, site classes, source and path parameters.

* Corresponding author: T: +44-20-7594-5984, F: +44-20-7594-5934, E: j.bommer@imperial.ac.uk 


\section{INTRODUCTION}

The development of a strong-motion database from subduction events along the Peru-Chile trench is an essential step for ground-motion prediction in this region as well as other subduction zones in the world where there is a significant hazard from earthquakes along the interface between the subducting and overriding plates and within the subducting slab. The tectonic setting of the PeruChile region is characterised by the subduction of the relatively young ( $\sim 50 \mathrm{My})$ Nazca plate beneath the continental South American plate (Figure 1), which takes place at a convergence rate of 7-9 cm/year in the N78 ${ }^{\circ}$ direction (DeMets et al., 1990). Along the Peru-Chile subduction zone, two main types of seismicity can be identified: firstly, earthquakes occurring at the seismically coupled interface between the Nazca and South American plates (interface earthquakes) and secondly, seismicity related to the zone of extension in the interior of the descending Nazca plate (intraslab earthquakes). The Peruvian-Chilean subduction zone has frequently ruptured in great ( $M$ 2 8.0) destructive earthquakes during the last centuries, many of which have been thrust-faulting events occurring along the interface between the Nazca and South American Plates, although there have also been a number of damaging intraslab events. An example of the latter is the great event $\left(M_{w}\right.$ 8.1) that occurred on 25 January 1939, near the city of Chillán, which killed approximately 28,000 people and is amongst the most damaging events that have occurred in the seismic history of Chile (Beck et al., 1998).

The occurrence of great subduction events along the Peruvian-Chilean subduction zone is quite frequent, with 17 events of magnitude $\mathrm{M}_{\mathrm{w}} \geq 7.5$ registered during the last 50 years. In central Chile, the historical record of earthquakes starts with an event of magnitude M 9.4 in 1575 followed by great events in 1647 (M 8.4), 1730 (M 8.2), 1822 (M 8.4) and 1906 (M 8.3) (Comté et al., 1986). For instance, the great Valparaiso event of 17 August 1906 (M 8.3) caused widespread damage in central Chile and claimed thousands of lives. In recent years, the central Chile segment ruptured in a large interface earthquake on 3 March 1985 ( $M_{W}$ 8.0), which killed 177 people and caused extensive damage in the cities of Valparaiso and Viña del Mar. This latter event ruptured along a previously identified seismic gap in central Chile with high probabilities of recurrence for a large earthquake (e.g., Nishenko, 1985). The north-central Chile segment of subduction has also ruptured in great events in $1922\left(M_{w} 8.7\right), 1943\left(M_{w} 8.2\right)$ and 1995 ( $M_{w}$ 8.0). The south-central Chile segment, between $35^{\circ} \mathrm{S}$ and $37^{\circ} \mathrm{S}$, is another identified seismic gap, referred to as the Concepción-Constitución seismic gap, which has been extensively studied following the 1939 Chillán event. This segment ruptured in a great (M 8.5) earthquake in February 1835, which completely destroyed the city of Concepción. The last great earthquake in this region was the magnitude $M_{W} 8.8$ interface event that occurred on 27 February 2010, whose epicentre was 
located at $100 \mathrm{~km}$ from the city of Concepción. Preliminary reports indicated that this latter event had a death toll of more than 500 people and caused extensive damage to the cities of Concepción, Arauco and Coronel, affecting over 2 million people. South of this region, between 37-S and 46으, a great $M_{w} 9.5$ underthrusting event occurred on 22 May 1960, causing 1660 deaths and leaving 2 million people homeless. This event, the largest instrumentally-recorded in the world during the $20^{\text {th }}$ Century, had an estimated rupture length of about $1000 \mathrm{~km}$ (Cifuentes, 1989) and also induced a tsunami that spread across the Pacific.

In the southern Peru and northern Chile segment of subduction, major interface events occurred in 1868 (southern Peru) and 1877 (northern Chile) with magnitudes estimated between 8.5 and 9.0 (Lomnitz, 2004; Kausel, 1986; Dorbath et al., 1990). This region had been identified as a seismic gap with a high potential of occurrence of a great earthquake (Lomnitz, 2004; Kelleher, 1972; Nishenko, 1985; Comté \& Pardo, 1991; Delouis et al., 1996). The southern part of this region ruptured in a large interface event in July $1995\left(M_{W}\right.$ 8.0), which occurred south of the rupture zone of the 1877 event. Large intraslab-type events have also occurred in northern Chile in December $1950\left(M_{W}\right.$ 8.0) and 13 June $2005\left(M_{W}\right.$ 7.8). The northern part of this seismic gap, ruptured in a great interface event on 23 June $2001\left(M_{W} 8.4\right)$, along the rupture area associated with great 1868 southern Peru event. The 2001 event had a death toll of 80 causalities and caused severe damage in the cities of Ocoña, Arequipa, Tacna and Moquegua. Along the central region of Peru, the subduction processes have caused great earthquakes in $1746\left(\mathrm{M}\right.$ 8.5), $1940\left(\mathrm{M}_{\mathrm{W}} 8.1\right), 1942\left(\mathrm{M}_{\mathrm{W}}\right.$ 8.0), $1966\left(\mathrm{M}_{\mathrm{W}}\right.$ 8.1), $1970\left(\mathrm{M}_{\mathrm{W}}\right.$ 7.8), $1974\left(\mathrm{M}_{\mathrm{W}}\right.$ 8.1), $1996\left(\mathrm{M}_{\mathrm{W}}\right.$ 7.7) and $2007\left(\mathrm{M}_{\mathrm{W}}\right.$ 8.0), causing thousands of deaths. The Central Peru segment of the subduction zone, between the rupture areas of the $1974\left(M_{w}\right.$ 8.1) Lima event and the $1996\left(M_{w} 7.7\right)$ Nazca event (Tavera \& Bernal 2005), had also been identified as another seismic gap. This gap last ruptured in a $M_{W} 8.0$ event on 17 August 2007 in the Pisco region of Central Peru, causing 595 deaths and extensive damage in the cities of Pisco, Chincha and Cañete (Tavera et al., 2008).

In view of the threat that both interface and intraslab-type events pose to the Peru-Chile region, the compilation of a strong-motion database of subduction events that can be the basis of future ground-motion prediction studies is of prime relevance. In Chile, the first strong-motion instruments were deployed in 1970s by the Civil Engineering Department of the University of Chile (RENADIC network), which recorded the 3 March $1985\left(\mathrm{M}_{\mathrm{W}}\right.$ 8.0) Valparaiso events and associated aftershocks amongst other events. Presently, the RENADIC network consists of 20 analogue and 15 digital stations installed in Northern and Central Chile. A second network (DGF-DIC) was deployed by the Departments of Geophysics and Civil Engineering of the University of Chile and the Swiss Seismological Service as a part of a project to study the northern Chile seismic gap and has been in operation since 2001. The DGF-DIC network consists of 11 digital instruments 
installed in Northern Chile, from Arica to Antofagasta. These two networks have recorded several large events on 13 June $2005\left(\mathrm{M}_{\mathrm{W}}\right.$ 7.8) and 23 June 2001 ( $\mathrm{M}_{\mathrm{W}}$ 8.4), amongst others. The Geophysical Institute of Peru (IGP) deployed the first strong-motion instruments in Lima, which recorded the 1966, 1970, 1971 and 1974 Peruvian events. Currently, strong-motion networks in Peru are operated by IGP, the Japan-Peru Centre for Seismic Research and Disaster Mitigation (CISMID), the South American Regional Seismological Centre (CERESIS), the Catholic University of Peru (PUCP), and the Peruvian state water company (SEDAPAL). Recent significant events recorded by these networks include the 23 June $2001\left(M_{w} 8.4\right)$ and 15 August $2007\left(M_{w} 8.0\right)$ Pisco event.

This paper presents the work performed in order to develop a database of strong-motion records from events along the Peru-Chile subduction zone and associated information (metadata). The strong-motion data recorded by the different networks operators in Peru and Chile have been compiled and processed in a uniform manner, and information on the source parameters of the causative earthquakes, fault-plane geometries and local site conditions at the recording stations has been collected and reviewed. Earthquake parameters from different reporting agencies and published studies were examined to define reliable source parameters, fault-plane geometries and distance metrics. Additionally, geological and geotechnical information at the recording sites was collected from different sources and sites were classified according to various schemes.

\section{DATABASE DESCRIPTION}

The compiled database consists of 98 triaxial ground-motion recordings from 15 subduction-type events with moment magnitudes ranging from 6.3 to 8.4, recorded at 55 different sites in Peru and Chile, between 1966 and 2007. These accelerograms have been made available by local networks in Chile and Peru including the National Accelerographic Network of Chile (RENADIC, 23 records), the DGF-DIC network jointly operated by the Departments of Geophysics and Civil Engineering of the University of Chile (7 records), the Geophysical Institute of Peru (IGP, 8 records) and the Japan-Peru Centre for Seismic Research and Disaster Mitigation (CISMID, 12 records). Additionally, strong-motion records from the 1985 Valparaiso (Chile) sequence and from the 1966, 1970, 1971 and 1974 Peruvian events available at the COSMOS Virtual Data Centre (http://db.cosmos-eq.org) were also included in this database (48 records). The location of the strong-motion stations operating along the Peru-Chile subduction zone, from which recordings are presented in this study, is shown in Figure 2. The majority of the data from these agencies have been released in unprocessed format; however, in a few cases strong-motion records to which some level of processing has already been applied were also included. All strong-motion data 
included in this database are from either from free-field stations or instruments at the base of structures, at a total of 56 sites. In the context of this study, free-field recordings are defined as those obtained at stations in small shelters, isolated from any building influence. The other recordings are obtained from instruments at the basement of structures up to three storeys in height, although five recordings obtained at stations located at the basement of structures with more than 3 storeys were included in this database.

Figure 3 displays the distribution of the data in terms of magnitude, distance, focal depth, event type, and NEHRP (National Earthquake Hazards Reduction Program) site class. The methodology used in the determination of the seismological parameters, computation of distance metrics and assignment of sites is discussed in the following sections of this paper. Overall, all strong-motion data available are from moderate-to-large events $\left(6.3 \leq \mathrm{M}_{\mathrm{W}} \leq 8.4\right)$ recorded at distances of about 25-420 km from the fault plane. Approximately half of the entire dataset was recorded at short distances $\left(R_{\text {rup }} \leq 100 \mathrm{~km}\right)$ and consequently, a significant number of the ground motions are of large amplitudes; the level of peak ground acceleration (PGA) recorded during these events varies within a range of approximately $20-700 \mathrm{~cm} / \mathrm{s}^{2}$. Similarly, most of the data included in the dataset come from events with magnitudes $M_{w} 8 \pm 0.3$ and $M_{w} 7 \pm 0.2$. The distribution of focal depth with respect to rupture distance for recordings from both interface and intraslab-type events is shown in the upper right panel of Figure 3. The majority of the data from interface events was recorded at distances ranging from about 30 to $200 \mathrm{~km}$, while the intraslab dataset includes ground motions recorded at distances $R_{\text {rup }}$ greater than $100 \mathrm{~km}$. The lower panels of Figure 3 show the distribution of the data for interface and intraslab events by NEHRP site class. As seen from this figure, most of the strong-motion records available are from sites classified as NEHRP class C, C/D and D. Only one record from a NEHRP class D/E site is available and no data was recorded at very soft sites (NEHRP class E).

The effort has been focused on compiling and reviewing the available metadata, which entailed an evaluation of the earthquake-related parameters (i.e., magnitude, location and fault mechanism), classification of subduction events by type (i.e., interface or intraslab), computation of source-tosite distance metrics and characterisation of site conditions at recording stations using different parameters (i.e., surface geology descriptors, shear-wave velocity profiles, natural site period and normalised response spectra shapes). Site classes were assigned to the stations in Peru and Chile following various classification schemes used in ground-motion prediction equations (GMPEs) for subduction-zone environments, such as the NEHRP classification used by Atkinson \& Boore (2003, 2008), the New Zealand site classification scheme used by McVerry et al. (2006) and the scheme used by Zhao et al. (2006b). 


\subsection{Earthquake-related parameters}

The earthquake-related information was collected from various reporting agencies and publications and ranked by preferred importance order. The epicentral locations and depths of the events used in this study were selected as follows: special studies of mainshock and aftershock sequences with accurate relocations, determinations published in the Centennial catalogue (Engdahl \& Villaseñor, 2002) and locations and depths determined by the ISC. For the more recent events not included in the ISC catalogue, the location estimated by NEIC was adopted. Regional determinations reported by local agencies (e.g., Department of Geophysics, University of Chile, GUC; Geophysical Institute of Peru, IGP) were also used in this study when appropriate. The moment magnitude $\left(\mathrm{M}_{\mathrm{w}}\right)$ estimates and focal mechanism solutions for the earthquakes whose data are used in this study were obtained from the Harvard Centroid Moment Tensor database (CMT) when available, which was generally the case for the large earthquakes included herein with magnitude greater than 6.0 which occurred after 1976. For all pre-1976 events, moment magnitudes and focal mechanism solutions were collected from individual studies (e.g., Hartzell \& Langer, 1993; Pacheco \& Sykes, 1992; Abe, 1972). Other instrumental measures of magnitude were collected from the onlinecatalogues of the different reporting agencies (i.e., International Seismological Centre, ISC and National Earthquake Information Center, NEIC) and were also included in the metadata. Surface wave magnitude $\left(M_{S}\right)$ and body-wave magnitude $\left(m_{b}\right)$ estimates of the Peruvian-Chilean earthquakes determined by the ISC were collected; however, in cases where ISC magnitude determinations were not available, those estimated by NEIC were used instead. No estimates of moment magnitude $\left(M_{\mathrm{W}}\right)$ were available for the 5 January $1974\left(M_{\mathrm{S}} 6.6\right)$ event and the 3 March $1985\left(M_{S}\right.$ 6.4) aftershock. It was therefore assumed that $M_{S}$ estimates for these events were equivalent to moment magnitude estimates $\left(\mathrm{M}_{\mathrm{W}}\right)$. This approximation was validated by plotting moment magnitude values against the different magnitude scales for the events with $M_{W}, M_{S}$ and $\mathrm{m}_{\mathrm{b}}$ data reported. The characteristics of the events contributing data to the present study are listed in Table 1; their locations and focal mechanisms are shown in Figure 2.

Additionally, the earthquake events were classified in terms of the physical processes with which they were associated (i.e., interface or intraslab activity). The earthquake classification was made on the basis of focal mechanism, epicentral location, depth, and relative position with respect to trench axis. The dominant mechanism of interface-type earthquakes corresponds to thrust faulting on shallow-dipping planes that are oriented approximately parallel to the trench axis. At depths greater than the coupled plate interface, the stress regime changes from compressional to tensional, and thus normal faulting prevails. These normal mechanism events are associated with intraslab activity occurring within the subducted Nazca slab, at some distance down-dip from the seismically coupled interface. At intermediate depths, two types of intraslab earthquakes have 
been identified in this region (e.g., Lemoine et al., 2002): slab-push and slab-pull, which are associated with down-plate compression and extension, respectively. Along the Peru-Chile subduction zone, the occurrence of slab-pull events is relatively common in comparison with slabpush events, although some slab-push events have been occurred in north-central Chile (the 15 October 1997 Punitaqui earthquake) and central Peru (the 5 and 29 April 1991 earthquakes).

The differentiation between interface and intraslab events was performed using the definitions of style of faulting of Wells \& Coppersmith (1994) and the event depth and location with respect to the trench axis. As seen in Table 1, the interface events in this catalogue have a reverse mechanism and are limited to a maximum depth of $40 \mathrm{~km}$, which is consistent with the maximum depth extent of the seismically coupled zone found along different segments of the Peru-Chile subduction zone (e.g., Comté et al., 1994; Comté \& Suárez, 1995; Tichelaar \& Ruff, 1991). On the other hand, intraslab-type events in Table 1 have a normal mechanism and occur within the Nazca slab at depths from about $60 \mathrm{~km}$ to $110 \mathrm{~km}$. The location of these events in 3D space combined with information regarding their focal mechanism (Figure 1 and lower left panel of Figure 2) allows a fairly unambiguous classification between interface and intraslab events, particularly since the geometry of the subducting Nazca slab has been extensively documented. The geometry of the subducting Nazca plate is characterised by variations in the dip angle along the strike of the trench (Barazangi \& Isacks, 1976; Jordan et al., 1983; Cahill \& Isacks, 1992). Between latitude $2^{\circ} \mathrm{S}$ and $45^{\circ} \mathrm{S}$, the subducting Nazca plate is divided into four segments: northern and central Peru, from $8^{\circ} \mathrm{S}$ to $15^{\circ} \mathrm{S}$, where the subducted Nazca plate has a shallow dip of about $10^{\circ}$; southern Peru and northern Chile, from $15^{\circ} \mathrm{S}$ to $27^{\circ} \mathrm{S}$, where the Nazca Plate descends with a dip of $25^{\circ}$ to $30^{\circ}$. In Central Chile, from $27^{\circ} \mathrm{S}$ to $33^{\circ} \mathrm{S}$, the slab is again relatively flat, with a shallow dip angle of about $10^{\circ}$, and in southern Chile, from $33^{\circ} \mathrm{S}$ to $45^{\circ} \mathrm{S}$, the dip of the subducted slab increases to $30^{\circ}$.

The depth extent of the seismically-coupled plate interface along the Peru-Chile subduction zone is similarly well-documented. It has been estimated from the maximum depth of shallow-dipping reverse events (e.g., Tichelaar \& Ruff, 1991; Suárez \& Comté, 1993; Comté et al., 1994; Comté \& Suárez, 1995) and from the depth transition from compressional to extensional stress regime (e.g., Comté \& Suárez, 1995; Pardo et al., 2002). Based on the maximum depth of large $\left(M_{W}>6\right)$ underthrusting events located teleseismically, Tichelaar \& Ruff (1991) suggested that the maximum depth of the seismically coupled zone between plates along Chile extends down to 48-53 km and that there is a change in the maximum depth north of latitude $28^{\circ} \mathrm{S}$, where the coupled zone extends to depths of $36-41 \mathrm{~km}$. In contrast, studies using both locally and teleseismically recorded data in Northern Chile (Comté et al., 1994; Comté \& Suárez, 1995) suggest that the coupling zone, as defined by the maximum depth observed for shallow-dipping reverse events, extends consistently to about $40 \pm 10 \mathrm{~km}$ and no variations along the strike of the trench are appreciable. 
The maximum depth of the coupling zone may, however, extend up to $60 \pm 10 \mathrm{~km}$, if the depth transition from compressional to tensional stress regime observed along the upper part of the subducting slab is considered (Comté \& Suárez, 1995). This transition of stress field along Northern Chile segment occurs at depths greater than the maximum depth at which shallowdipping reverse events are observed $(\sim 40 \mathrm{~km})$. Along the Central Chile segment of the subduction zone, the maximum depth of the plate interface has also been estimated to be about $60 \mathrm{~km}$ (Pardo et al., 2002), which is in agreement with the above mentioned studies along different segments of the Chilean subduction zone.

\subsection{Station information and assignment of site conditions}

The coordinates of the stations used in this study, type of instruments and instrument housing are listed in Tables 2 and 3 and their geographical distribution is shown in Figure 2. For the stations in Central Chile that recorded the 1985 Valparaiso earthquake sequence, some of which are no longer in operation, the station coordinates listed correspond to those reported by Campbell et al. (1989, 1990), which were validated against satellite imagery (i.e., Google Earth) to ensure accuracy. Information on the type and location of instrument (i.e., type of building) was also obtained from these references, from the accelerogram headings and from the websites of the network operators (IGP, CISMID, RENADIC and DGF-DIC). Information on the majority of the Peruvian stations included herein has already been presented in Tavera et al. (2008).

Tables 2 and 3 also summarise all geological and geotechnical information collected for the sites contributing data to this study. Site conditions assigned to the stations in Central Chile were based on information collected from a number of references including descriptions of the surface geology (EERI, 1986; Çelebi, 1987, 1988; Campbell et al., 1989, 1990; Midorikawa et al., 1991; Midorikawa, 1992), the site categories following the Chilean seismic design code assigned by Riddell (1995) and NEHRP site classes assigned by Atkinson \& Boore (2003) to the Chilean sites whose data were included in the regression database for subduction-zone events. Shear-wave velocity $\left(\mathrm{V}_{\mathrm{S}}\right)$ profiles obtained by Araneda \& Saragoni (1994), Midorikawa et al. (1991) and Midorikawa (1992) in addition to the natural period of the Chilean sites determined by Luppichini (2004) using the records of the 1985 Valparaiso earthquake, were also used. Site conditions at the strong-motion stations in northern Chile are still under investigation and geological and geotechnical information for a number of these stations has not yet been made available to the wider engineering community. It is believed, however, that recording sites in northern Chile can be classified as NEHRP class $\mathrm{C}$, with an average shear-wave velocity over the top $30 \mathrm{~m}, \mathrm{~V}_{\mathrm{S} 30}$, between 400 and $600 \mathrm{~m} / \mathrm{s}$ (Boroschek \& Comté, 2006). Therefore, site conditions assigned to these sites were only based on information from descriptions of the local geology (SNGM, 1982), 
$V_{S}$ profiles obtained from SASW (spectral analysis of surface waves) measurements at the stations in Arica and Poconchile (Cortez-Flores, 2004), and natural site periods estimated by site response analysis for the Arica and Poconchile stations (Cortez-Flores, 2004).

Site conditions assigned to the stations in Central and Southern Peru were based on descriptions of the surface geology (EERI, 2007; Bernal \& Tavera, 2007a, 2007b) and the site category (i.e., rock, soil or firm ground) assigned by Rodriguez-Marek et al. (2007). Shear-wave velocity ( $\mathrm{V}_{\mathrm{s}}$ ) profiles obtained from SASW measurements at the stations in Ica (Rosenblad \& Bay, 2008) and the stations in Moquegua and Tacna (Cortez-Flores, 2004), as well as the $V_{S}$ profiles estimate by Bernal \& Tavera (2007a, 2007b) using an infinite flat-layered half-space model were also used. Additionally, the natural site period as interpreted from the microzonation map of Lima (Aguilar Bardales \& Alva Hurtado, 2007) and that estimated by site response analysis for the Moquegua and Tacna sites (Cortez-Flores, 2004) were included. Information on the site conditions of the majority of the Peruvian stations included herein has been also been reported in Tavera et al. (2008).

Besides the site information collected, the spectral shapes of the records were considered by normalising the response spectra by their PGA value (for all records) and by dividing the spectra recorded at soil stations by the spectrum obtained on rock, for stations sufficiently close to one another. The natural period for each site computed from earthquake records, $T_{0, \text { REC }}$, was also estimated and used as a guide for the assignation of site classes, following the empirical site classification approach (JP) adopted by Zhao et al. (2006a) which defines the site period as that corresponding to the highest $\mathrm{H} / \mathrm{V}$ response spectral ratio. Tables 2 and 3 also list the site classes assigned to the different stations following several classification schemes: the NEHRP site classification, which is based on the average shear-wave velocity over the top $30 \mathrm{~m}$; the New Zealand classification scheme used by McVerry et al. (2006), which classifies sites on the basis of the surface geology, geotechnical properties, site period and depth to bedrock; and the scheme used by Zhao et al. (2006b), which uses the predominant site period from $\mathrm{H} / \mathrm{V}$ response spectral ratios

Due to the inherent limitations of some of site data collected, the same level of priority was not given to all the various pieces of information in the assignment of site classes. For instance, only $\mathrm{V}_{\mathrm{S}}$ profiles determined from measurements of shear-wave velocity conducted in the field have been used for the direct assignment of site classes, and profiles reported in inversions (e.g., Bernal \& Tavera, 2007a; 2007b) have only been used to distinguish between shallow and deep soil sites since in several instances these profiles have been found to be biased towards low values, leading to site classifications that are inconsistent with other geological and geotechnical descriptions. 
Similarly, the $\mathrm{V}_{\mathrm{S} 30}$ values listed in Table 2, calculated from the $\mathrm{V}_{\mathrm{S}}$ profiles estimated by Araneda \& Saragoni (1994) at a number of sites in central Chile (i.e., LLAY, MEL, ISI), were found to be biased towards high values. As no information as to the manner in which the $V_{S}$ values published in Araneda \& Saragoni (1994) were obtained (i.e., in situ measurements or numerical modelling), these $V_{S}$ profiles have only been used to identify different soil depths. In addition, the natural period ( $T_{0,}$ CIS $)$ derived using ambient noise measurements mapped in the microzonation map of Lima (Aguilar Bardales \& Alva Hurtado, 2007), was generally the preferred input for assigning the JP site classes to the Peruvian sites as the predominant period calculated directly from the records ( $T_{0}$, REC $)$ could be biased due to non-linearity effects. In some instances, however, it was found that mapped period was inconsistent with other site descriptors, possibly due to limitations of the mapping resolution. For the stations in Chile, natural periods estimated by site response analysis (Cortez-Flores, 2004) were the preferred input.

Most of the stations in central Chile are situated on dense alluvial gravel and sand classified as NEHRP class C, C/D and D. There are no stations situated on soft soil (NEHRP E); however, the VMAR and V-ALM stations are on deep sand and artificial fill respectively and therefore exhibit features consistent with soils of medium density. These sites are classified as NEHRP D in view of the large values of the $V_{S 30}$ reported. Only three stations are located on hard rock and rock (NEHRP class $A$ and B), and three sites are on soft/weathered rock classified as NEHRP class C: the RAP, VIL and UTFSM stations are located on rock (NEHRP site class B) and ZAP, QUI, PIC sites are on soft/weathered rock (NEHRP site class C). Stations in Northern Chile are situated on volcanic rock and shallow fill on weathered rock, classified as NEHRP B and C respectively. The most recent material in this region consists of Quaternary alluvial and fluvial deposits and many of the stations are located on such material. These sites are therefore classified as NEHRP $C$ by virtue of the $\mathrm{V}_{\mathrm{S} 30}$ values estimated for some of those sites (ACA, ACO, POCO1, POCO2) as well as the shape of the normalised spectra (IQU, MEJI, PICA, CUY). The majority of the stations in Peru used in this study are situated on alluvial gravel, sand and silt and have been classified as NEHRP class $C$ and $D$ and only one station (NNA) is situated on rock classified as NEHRP class B. Conversely, the station CAL is located close to the coast in an area of reclaimed land over soft soil, and has been classified as NEHRP class D/E. Another station located on reclaimed land is RIN, which is located on loose granular fill composed of gravel, silt and fine sand.

\subsection{Record information}

Processing was performed with the suite of programmes for processing and manipulation of time series developed by Dr David Boore from United States Geological Survey (USGS) (Boore, 2008). 
The ground-motion recordings were reformatted and converted into SMC-format files (see http://nsmp.wr.usgs.gov/smcfmt.html for details). When necessary, unevenly sampled data were interpolated and resampled at 200 samples per second. Before the application of any processing procedure, non-standard noise (i.e., spurious spikes) encountered in digitized records from analogue instruments (Douglas, 2003) was identified by visual inspection of the jerk (derivative of the acceleration trace). Spikes identified as erroneous, were removed by replacing the acceleration ordinate of the spike with the mean of the preceding and proceeding accelerations values. For some of the analogue recordings included in this database, instrument correction has been already applied by the data provider and thus not applied here. Instrument corrections were not applied to the remaining records from analogue instruments in this database as, in some cases, complete information on the instruments response was not available and additionally, the application of an instrument correction can result in amplification of high-frequency noise introduced during the digitization process (Boore \& Bommer, 2005). As a result of the dynamic range of the digital instruments (natural frequencies of $100 \mathrm{~Hz}$ or higher) corrections for instrument characteristics were not applied to the digital recordings included in the database

The records were processed in a consistent manner, with individual components individually filtered. Before performing the actual filtering of the record, an initial baseline correction was applied to the raw accelerogram (zero ${ }^{\text {th }}$-order correction). The mean determined from the pre-event portion of the record, or the mean computed from the whole record if the pre-event portion was not available, was subtracted from the entire acceleration time series. After making this initial baseline correction, the acceleration traces were integrated without filtering, to check for long-period drifts that could indicate the presence of offsets in the reference baseline. In most cases baseline offsets were small and the long-period noise was removed by filtering. The records were then filtered using an acausal bi-directional, eighth-order Butterworth filter. For digital records, low-cut filter frequencies were determined by considering the signal-to-noise ratio between each channel and a model of the noise obtained from the pre-event memory. Since this type of model does not account for "signal-generated" noise (Boore \& Bommer, 2005), the results were checked through visual inspection of the velocity and displacement traces obtained from integration of the filtered acceleration record. Visual inspection of these traces was also the basis for the selection of the low-cut filter frequency when no pre-event memory of digital records was available. For analogue records, fixed traces were not available to allow the identification of low-frequency noise. Therefore, the Fourier Amplitude Spectrum (FAS) of the unfiltered accelerogram was compared with the noise spectrum estimated from studies of instruments and digitising apparatus such as those proposed by Lee \& Trifunac (1990) and Skarlatoudis et al. (2003), which were used as guide for the selection of low-cut filters. Since these studies correspond to a particular combination of accelerograph and digitiser, which does not correspond to that of data being processed, visual 
examination of the velocity and displacement traces was also used as a basis for the selection of the low-cut filter frequency.

In selecting low-cut filter frequencies, the filter parameter was chosen to give a signal-to-noise ratio of 2. It is noted that the comparison of the Fourier Amplitude Spectrum (FAS) of the record with that of the noise indicates the ratio of signal-plus-noise to noise, hence if the desired target is a signal-to-noise ratio of 2 , the ratio of the record FAS to that of the noise model should be 3 . The maximum usable period of the spectrum was then defined as 0.8 times the low-cut filter period, as suggested by Abrahamson \& Silva (1997), which is broadly consistent with the limits suggested by Akkar \& Bommer (2006). On this basis it was decided that, for about $85 \%$ of the records included in the database, the spectral ordinates could be reliably calculated up to $3 \mathrm{sec}$ (or up to $4 \mathrm{sec}$ or longer for digital records), although for a few analogue accelerograms, the usable period range could only be extended up to 2 sec. Finally, removal of high-frequency noise was achieved by using high frequency cut-off filters at $25 \mathrm{~Hz}$ for records from analogue instruments and $50 \mathrm{~Hz}$ for records from digital instruments. Peak values of acceleration and velocity and acceleration response spectra values for $5 \%$ of the critical damping were then obtained from the processed data.

The other relevant parameter for each record is the source-to-site distance. The source-to-site distance was characterised in terms of the closest distance to the earthquake fault plane or rupture distance $\left(\mathrm{R}_{\text {rup }}\right)$. Fault plane dimensions and orientations were obtained from published finite-source rupture models when available (e.g., Abe, 1972; Hartzell \& Langer, 1993; Mendoza et al., 1994; Choy \& Dewey, 1988; Pritchard et al., 2007; Ji \& Zeng, 2007). Events for which fault-plane geometries from finite-fault inversion were available have moment magnitudes $7.1 \leq M_{W} \leq 8.4$ and contribute $70 \%$ of the strong-motion data included in the database. For the $1966\left(M_{W} 8.1\right)$ and 1970 $\left(M_{w}\right.$ 8.0) Peruvian earthquakes, the rupture areas assumed for source-to-site distance computations were those estimated by Abe (1972) based on early aftershocks distributions; these two events only contribute two records. For the aftershocks of the 1985 Valparaiso event, with moment magnitudes $6.3 \leq \mathrm{M}_{\mathrm{W}} \leq 7.1$, the circular rupture geometries determined by Choy \& Dewey (1988) were used to estimate the corresponding rupture distances.

For the remaining events, for which neither finite source models nor reliable distribution of early aftershocks were available, an alternative approach was used to estimate the distance metrics. Fault-rupture dimensions were estimated from empirical relationships between rupture area and moment magnitude $\left(\mathrm{M}_{\mathrm{w}}\right)$ for interface and intraslab-type events that have been determined in Strasser et al. (2010). The rupture plane was then located in space, assuming that the epicentre lies above the centre of a dipping plane. The strike, dip and rake of the fault plane were assumed 
to correspond to the preferred focal plane of the two sets of angles listed in the Harvard CMT catalogue. On the other hand, for intraslab-type events the main focal plane was assumed to be that suggested by individual studies of these events. For instance, for the 15 October $1997\left(\mathrm{M}_{\mathrm{W}}\right.$ 7.1) Punitaqui event, the orientation of the actual fault plane was estimated to be the almost vertical nodal plane of the two sets of angles reported in the Harvard CMT catalogue, based on the body-wave modelling for this event carried out by Lemoine et al. (2001). Similarly, the orientation of the preferred focal planes for the 7 November $1981\left(M_{S} 6.7\right)$ and the 5 January $1974\left(M_{S} 6.7\right)$ events used herein were those suggested by Astiz \& Kanamori (1986) and Langer \& Spence (1995) respectively. This approach is expected to be a reasonable approximation for the purpose of source-to-site distance calculations in view of the fact that most of the events for which this assumption was applied correspond to intraslab events with magnitude $5.9 \leq \mathrm{M}_{S} \leq 6.8$, which were recorded at large distances and thus their fault dimensions are not likely to be very large compared to the source-to-site distances.

\section{CONCLUSIONS}

A database of recordings for the Peru-Chile region from 1966 to 2007 has been compiled, with particular emphasis on the quality of both the data and the metadata associated with the recordings. The development of reliable regional strong-motion databases for subduction events is therefore of prime importance as they increase the confidence in the results of both regional and global ground-motion prediction studies for subduction regimes. While the database presented in this study is not sufficient for the derivation of a new predictive equation for ground motions from subduction-type events in the Peru-Chile region, it significantly expands the global database of strong-motion data and associated metadata that can be used in the derivation of predictive equations for subduction environments. Indeed, the compiled database further extends the magnitude range of the currently available global databases for interface events (e.g., Youngs et al., 1997; Atkison \& Boore, 2003; 2008) by the inclusion of data from the $2001\left(M_{W}\right.$ 8.4) Peruvian event and further supplements the global intraslab data by the inclusion of recordings from the $2005\left(M_{w}\right.$ 7.8) Chilean event. Although the database presented in this paper includes strongmotion data recorded from 1966 to 2007, the present work can be easily extended to include more recordings and metadata from this region as they become available, including those from the $M_{w}$ 8.8 that struck Chile on 27 February 2010, as this study was being finalised.

The compiled database will also allow the assessment of the existing predictive models for subduction-type events in terms of their suitability for this region, which directly influences the seismic hazard assessment in this region. 


\section{ACKNOWLEDGMENTS}

The doctoral research of the first author, on which this paper is based, has been partially funded by the AIßan Programme of the European Union under scholarship E05D053967CO and the COLFUTURO programme; their financial support is gratefully acknowledged. The authors thank Bertrand Delouis for providing information on the source process of the 13 June 2005 Chilean earthquake.

We are grateful to two anonymous reviewers for their constructive feedback that helped to improve the manuscript. 


\section{REFERENCES}

Abe, K. (1972). Mechanics and tectonic implications of the 1966 and 1970 Peru earthquakes. Physics of the Earth and Planetary Interiors 5, 367-379.

Abrahamson, N.A., and W.J. Silva (1997). Empirical response spectral attenuation relations for shallow crustal earthquakes. Seismological Research Letters 68(1), 94-127.

Aguilar Bardales, Z., and J. Alva Hurtado (2007). Seismic microzonation of Lima. Proceedings of the International Conference on Earthquake Engineering, Centro Peruano Japonés de Investigaciones Sismicas y Mitigación de Desastres (CISMID), Universidad Nacional de Ingeniería, Lima, Peru. Available online at: http://www.cismid.edu.uni.pe/descargas/redacis/redacis32_p.pdf [in Spanish, last accessed: November 2009].

Akkar, S. and J.J. Bommer (2006). Influence of long-period filter cut-off on elastic spectral displacements. Earthquake Engineering \& Structural Dynamics 35(9), 1145-1165.

Araneda, C., and G.R. Saragoni (1994). Project of geological survey of strong motion site in Central Chile. Report for the Kajima Institute of Construction Technology of Tokyo, Santiago, Chile.

Astiz, L., T. Lay, and H. Kanamori (1988). Large intermediate-depth earthquakes and the subduction process. Physics of the Earth and Planetary Interiors 53(1-2), 80-166.

Atkinson, G.M., and D.M. Boore (2003). Empirical ground-motion relations for subduction-zone earthquakes and their application to Cascadia and other regions. Bulletin of the Seismological Society of America 93(4), 1703-1729.

Atkinson, G.M., and D.M. Boore (2008). Erratum to: Empirical ground-motion relations for subduction-zone earthquakes and their application to Cascadia and other regions. Bulletin of the Seismological Society of America 98(4), 2567-2569.

Barazangi, M., and B.L. Isacks (1976). Spatial distribution of earthquakes and subduction of the Nazca plate beneath South America. Geology 4(11), 686-692.

Beck, S., S. Barrientos, E. Kausel, and M. Reyes (1998). Source characteristics of historic earthquakes along the central Chile subduction zone. Journal of South American Earth Sciences 11(2), 115-129.

Bernal I., and H. Tavera (2007a). Peak accelerations recorded in the City of Lima. In : The August 15, 2007 (7.0 ML) Pisco Earthquake (Preliminary report). Dirección de Sismología, Instituto Geofísico del Perú (IGP) [in Spanish].

Bernal I., and H. Tavera (2007b). Peak accelerations recorded in the City of Ica. In : The August 15, 2007 (7.0 ML) Pisco Earthquake (Preliminary report). Dirección de Sismología, Instituto Geofísico del Perú (IGP) [in Spanish].

Boore (2008). TSMMP Suite of Programmes for time series processing. Available online from http://quake.usgs.gov/ boore/software online.htm [last accessed December 2009]. 
Boore, D.M., and J.J. Bommer (2005). Processing of strong-motion accelerograms: needs, options and consequences. Soil Dynamics and Earthquake Engineering 25(2), 93-115.

Boroschek, R., and D. Comte (2006). Amplitude and frequency characteristics of the 2001 Southern Peru, $M_{w}=8.4$ earthquake records. Journal of Seismology 10(3), 353-369.

Cahill, T. and B.L. Isacks (1992). Seismicity and shape of the subducted Nazca plate. Journal of Geophysical Research 97(B12), 17503-17529.

Campbell, K.W., S.T. Algermissen, E. Kausel, and L.M. Highland (1989). Processed strong-motion data for the Central Chile earthquake of March 3, 1985: Fifteen accelerograph sites owned by CHILECTRA, ENDESA, and the Department of Geology and Geophysics, University of Chile. Open-File Report 89-448, U.S. Geological Survey, 328 pp.

Campbell, K.W., S.T. Algermissen, E. Kausel, and L.M. Highland (1990). Processed strong-motion data for the Central Chile aftershock of April 9, 1985: Nine accelerograph sites owned by CHILECTRA, ENDESA, and the Department of Geology and Geophysics, University of Chile. Open-File Report 90-46, U.S. Geological Survey, 171 pp.

Ceelebi, M. (1987). Topographical and geological amplifications determined from strong-motion and aftershock records of the 3 March 1985 Chile earthquake. Bulletin of the Seismological Society of America 77(4), 1147-1167.

Çelebi, M. (1988). Processed Chile earthquake Records of 3 March 1985 and Aftershocks. OpenFile report 87-195, revised October 1988, U.S. Geological Survey, 254 pp.

Choy, G.L., and J.W. Dewey (1988). Rupture process of an extended earthquake sequence: Teleseismic analysis of the Chilean earthquake of March 3, 1985. Journal of Geophysical Research 93(B2), 1103-1118.

Cifuentes, I. L. (1989) The 1960 Chilean earthquakes Journal of Geophysical Research 94 (B1), 665-680.

Comte, D., and M. Pardo (1991). Reappraisal of great historical earthquakes in the northern Chile and southern Peru seismic gaps. Natural Hazards 4(1), 23-44.

Comte, D., and G. Suárez (1995). Stress distribution and geometry of the subducting Nazca plate in northern Chile using teleseismically recorded earthquakes. Geophysical Journal International 122(2), 419-440.

Comte, D., A. Eisenberg, E. Lorca, M. Pardo, I. Ponce, R. Saragoni, S.K. Singh, and G. Suárez (1986). The 1985 Central Chile Earthquake: A repeat of previous great earthquakes in the region? Science 233(4762), 449-453.

Comte, D., M. Pardo, L. Dorbath, C. Dorbath, H. Haessler, L. Rivera, A. Cisternas, and L. Ponce (1994). Determination of seismogenic interplate contact zone and crustal seismicity around Antofagasta, northern Chile using local data. Geophysical Journal International 116(3), 553-561. 
Cortez-Flores, A. (2004). Site response of the 2001 Southern Peru earthquake. MSc Thesis, Washington State University.

Delouis, B., and D. Legrand (2007). $M_{w} 7.8$ Tarapaca intermediate depth earthquake of 13 June 2005 (northern Chile): Fault plane identification and slip distribution by waveform inversion. Geophysical Research Letters 34(1), Article No. L01304.

Delouis, B., A. Cisternas, L. Dorbath, L. Rivera, and E. Kausel (1996). The Andean subduction zone between 22 and $25^{\circ} \mathrm{S}$ (northern Chile): precise geometry and state of stress. Tectonophysics 259(1-3), 81-100.

DeMets, C., R.G. Gordon, D.F. Argus, and S. Stein (1990). Current plate motions. Geophysical Journal International 101(2), 425-478.

Dewey, J.W., G.L. Choy, and S.P. Nishenko (1985). Asperities and paired thrust zones in the focal region of the Chilean earthquake of March 3, 1985. Eos Transactions of the American Geophysical Union 66, 950 [Abstract].

Dorbath, L., A. Cisternas, and C. Dorbath (1990). Assessment of the size of large and great historical earthquakes in Peru. Bulletin of the Seismological Society of America 80(3), 551-576.

Douglas, J. (2003). What is a poor quality strong-motion record? Bulletin of Earthquake Engineering 1(1), 141-156.

EERI (1986). The Chile Earthquake of March 3, 1985 - EERI Reconnaissance Report. Earthquake Spectra 2(2), 249-508.

EERI (2007). Learning from earthquakes: The Pisco, Peru, Earthquake of August 15, 2007. EERI Special Earthquake Report, EERI Newsletter, October 2007.

Engdahl, E.R., and A. Villaseñor (2002). Global Seismicity:1900-1999. In: Lee , W.H.K., H. Kanamori, P.C. Jennings, and C. Kisslinger (eds), International Handbook of Earthquake and Engineering Seismology. Academic Press. Part A, Ch. 41, p. 665-690.

Engdahl, E.R., R. van der Hilst, and R. Buland (1998). Global teleseismic earthquake relocation with improved travel times and procedures for depth determination. Bulletin of the Seismological Society of America 88(3), 722-743.

Espinosa A. F., R. Husid, S. T. Algermissen, and J. De las Casas (1977). The Lima earthquake of October 3, 1974; intensity distribution. Bulletin of the Seismological Society of America 67(5):14291439.

Hartzell, S., and C. Langer (1993). Importance of model parameterization in finite fault inversions: Application to the $1974 \mathrm{M}_{\mathrm{w}}$ 8.0 Peru earthquake. Journal of Geophysical Research 98 (B12), 22123-22134. 
Ji, C., and Y. Zeng (2007). Preliminary results of the August 15, $2007 \mathrm{M}_{\mathrm{w}} 8.0$ coast of central Peru earthquake. U.S. Geological Survey web report, available online at http://earthquake.usgs.gov/eqcenter/eqinthenews/2007/us2007gbcv/finite fault.php [last accessed: November 2009]

Jordan, T.E., B.L. Isacks, R.W. Allmendinger, J.A. Brewer, V.A. Ramos, and C.J. Ando (1983). Andean tectonics related to geometry of subducted Nazca plate. Bulletin of the Geological Society of America 94(3), 341-361.

Kausel, E. (1986). Los Terremotos de Agosto de 1868 y Mayo de 1877 que afectaron el Sur del Peru y Norte de Chile. Boletin de la Academia Chilena de Ciencias 3, 8-12.

Kelleher, J.A. (1972). Rupture zones of large South American earthquakes and some predictions. Journal of Geophysical Research 77(11), 2087-2103.

Langer, C.J. and W. Spence (1995). The 1974 Peru earthquake series. Bulletin of the Seismological Society of America 85(3), 665-687.

Lee, V.W., and M.D. Trifunac (1990). Automatic digitization and processing of accelerograms using PC. Report CE-90-03, Department of Civil Engineering, University of Southern California, Los Angeles, California, 115pp.

Lemoine, A., R. Madariaga, and J. Campos (2001). Evidence for earthquake interaction in Central Chile: the July 1997-September 1998 sequence. Geophysical Research Letters 28(14), 27432746.

Lemoine, A., R. Madariaga, and J. Campos (2002). Slab-pull and slab-push earthquakes in the Mexican, Chilean and Peruvian subduction zones. Physics of the Earth and Planetary Interiors 132(1-3), 157-175.

Lomnitz, C. (2004). Major earthquakes of Chile: A historical survey, 1535-1960. Seismological Research Letters 75(3), 368-378.

Luppichini, N. (2004). Interpretación de los acelerogramas del terremoto de Chile Central de 1985 considerando ondas sísmicas de alta frecuencia. Civil Engineering Dissertation, University of Chile.

McVerry, G., J. Zhao, N. Abrahamson, and P. Somerville (2006). New Zealand acceleration response spectrum attenuation relations for crustal and subduction zone earthquakes. Bulletin of the New Zealand Society for Earthquake Engineering 39(1), 1-58.

Mendoza, C., S. Hartzell, and T. Monfret (1994). Wide-band analysis of the 3 March 1985 central Chile earthquake: Overall source process and rupture history. Bulletin of the Seismological Society of America 84(2), 269-283.

Midorikawa, S. (1992). Site effects on strong-motion records of the 1985 Chile earthquake and their non-linear behaviour. Proceedings of the $10^{\text {th }}$ World Conference in Earthquake Engineering, Madrid, Spain, 19-24 July 1992, Vol. 2, p.1031-1036. 
Midorikawa, S., R. Riddell, and E. Cruz (1991). Strong-motion accelerograph array in Santiago, Chile, and preliminary evaluation of site effects. Earthquake Engineering \& Structural Dynamics 20(5), 403-407.

NEHRP (1997). Recommended provisions for seismic regulations for new buildings and other structures. Report FEMA 303, U.S. Federal Emergency Management Agency, Washington, DC.

Nishenko, S.P. (1985). Seismic potential for large and great interplate earthquakes along the Chilean and southern Peruvian margins of South America: A quantitative reappraisal. Journal of Geophysical Research 90(B5), 3589-3616.

Pacheco J. F and L. R. Sykes (2002). Seismic moment catalog of large shallow earthquakes, 1900 to 1989. Bulletin of the Seismological Society of America 82(3):1306-1349

Pardo, M., D. Comte, and T. Monfret (2002). Seismotectonic and stress distribution in the central Chile subduction zone. Journal of South American Earth Sciences 15(1), 11-22.

Pritchard, M., E. Norabuena, C. Ji, R. Boroschek, D. Comte, M. Simons, T. Dixon, and P. Rosen (2007). Geodetic, teleseismic, and strong motion constraints on slip from recent southern Peru subduction zone earthquakes. Journal of Geophysical Research 112(B3), 1-24.

Riddell, R. (1995). Inelastic design spectra accounting for soil conditions. Earthquake Engineering and Structural Dynamics 24(11), 1491-1510.

Rodriguez-Marek, A., J.D. Bray, and N. Abrahamson (2001). An empirical geotechnical seismic site response procedure. Earthquake Spectra 19(3), 653-675.

Rodriguez-Marek, A., J. Hurtado, B.Cox, J. Meneses, V. Moreno, M. Olcese, R. Sancio, and J. Wartman (2007). Preliminary Reconnaissance Report on the Geotechnical Engineering Aspects of the August 15, 2007 Pisco, Peru Earthquake. Report of the National Science FoundationSponsored Geotechnical Earthquake Engineering Reconnaissance (GEER) Team. Web report available from: http://gees.usc.edu/GEER/Peru_2007/Peru_2007_WebPag e/index.htm [last accessed: November 2009].

Rosenblad, B.L., and J.A. Bay (2008). Shear wave velocity profiles determined from SASW measurements at sites affected by the August $15^{\text {th }}, 2007$ earthquake in Peru. Report prepared for CERESIS, January 2008, $60 \mathrm{pp}$.

Skarlatoudis, A., C. Papazachos, and B. Margaris (2003). Determination of noise spectra from strong motion data recorded in Greece. Journal of Seismology 7(4), 533-540.

SNGM (1982). 1:250,000 geologic map of Chile. Servicio Nacional de Geologia y Mineria, Chile.

Strasser F.O, M.C. Arango and J.J. Bommer (2010). Scaling of source dimensions for interface and intraslab subduction-zone earthquakes with moment magnitude. Seismological Research Letters, submitted 
Suárez, G., and D. Comte (1993). Comment on 'Seismic coupling along the Chilean subduction zone' by B. W. Tichelaar and L. R. Ruff. Journal of Geophysical Research 98(B9), 15825-15828.

Tavera, H., and I. Bernal (2005). Spatial distribution of rupture areas and seismic gaps in western Peru. Special Volume N6 commemorating Alberto Giesecke, Geological Society of Peru, 89-92 [in Spanish].

Tavera, H., I. Bernal, F.O. Strasser, M.C. Arango-Gaviria, J.E. Alarcon, and J.J. Bommer (2008). Ground motions observed during the 15 August 2007 Pisco, Peru, earthquake. Bulletin of Earthquake Engineering 7(1), 71-111.

Tichelaar, B.W., and L.J. Ruff (1991). Seismic coupling along the Chilean subduction zone. Journal of Geophysical Research 96(B7), 11997-12022.

Wells, D.L., and K.J. Coppersmith (1994). New empirical relationships among magnitude, rupture length, rupture width, rupture area, and surface displacement. Bulletin of the Seismological Society of America 84(4), 974-1002.

Youngs, R.R., S.J. Chiou, W.J. Silva, and J.R. Humphrey (1997). Strong ground motion attenuation relationships for subduction zone earthquakes. Seismological Research Letters 68(1), 58-77.

Zhao, J., K. Irikura, J. Zhang, Y. Fukushima, P. Somerville, A. Asano, Y. Ohno, T. Oouchi, T. Takahashi, and H. Ogawa (2006a). An empirical site-classification method for strong-motion stations in Japan using $\mathrm{H} / \mathrm{V}$ response spectral ratio. Bulletin of the Seismological Society of America 96(3), 914-925.

Zhao, J.X., J. Zhang, A. Asano, Y. Ohno, T. Oouchi, T. Takahashi, H. Ogawa, K. Irikura, H.K. Thio, P.G. Somerville, and Y. Fukushima (2006b) Attenuation relations of strong ground motion in Japan using site classification based on predominant period. Bulletin of the Seismological Society of America 96(3), 898-913. 


\section{FIGURES}

Figure 1: Tectonic setting and distribution of seismicity along the Peru-Chile subduction zone. Seismicity corresponds to that reported in EHB Bulletin for the period 1960-2006. The width and direction of the cross sections of seismicity are indicated by the rectangle in the map.

Figure 2: Location of the strong-motion stations used in this study. The panels show the stations located in (a) Central and Southern Peru; (b) Northern Chile; and (c) Central Chile. The locations and focal mechanisms of the events contributing data to this study are also shown.

Figure 3: Distribution of the dataset in terms of magnitude, distance, focal depth, event type, and NEHRP site class.

\section{TABLES}

Table 1. Summary of the earthquakes recorded In Peru and Chile, whose data is used for this study. $M_{w}$ estimates were obtained from Harvard CMT catalogue, except for those events not included in there, for which $M_{S}$ estimates have been listed instead (values followed by asterisk). The source of the fault geometry used to compute the rupture distance $\left(R_{\text {rup }}\right)$ is also listed along with the number of records available from each event and the distance and PGA range. Other parameters listed include the hypocentral location, the style-of-faulting and dimensions of the fault rupture (see notes at foot of table).

Table 2: Summary of characteristics of Chilean strong-motion stations used in this study.

Table 3: Summary of characteristics of Peruvian strong-motion stations used in this study. 
Table 1. Summary of the earthquakes recorded In Peru and Chile, whose data is used for this study. $\mathrm{M}_{\mathrm{w}}$ estimates were obtained from Harvard CMT catalogue, except for those events not included in there, for which $M_{S}$ estimates have been listed instead (values followed by asterisk). The source of the fault geometry used to compute the rupture distance $\left(R_{\text {rup }}\right)$ is also listed along with the number of records available from each event and the distance and PGA range. Other parameters listed include the hypocentral location, the style-of-faulting and dimensions of the fault rupture (see notes at foot of table).

Depth

[km]

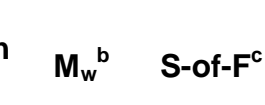

[15:01:08]

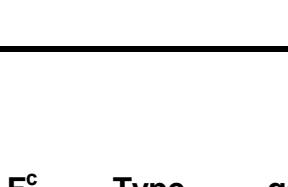




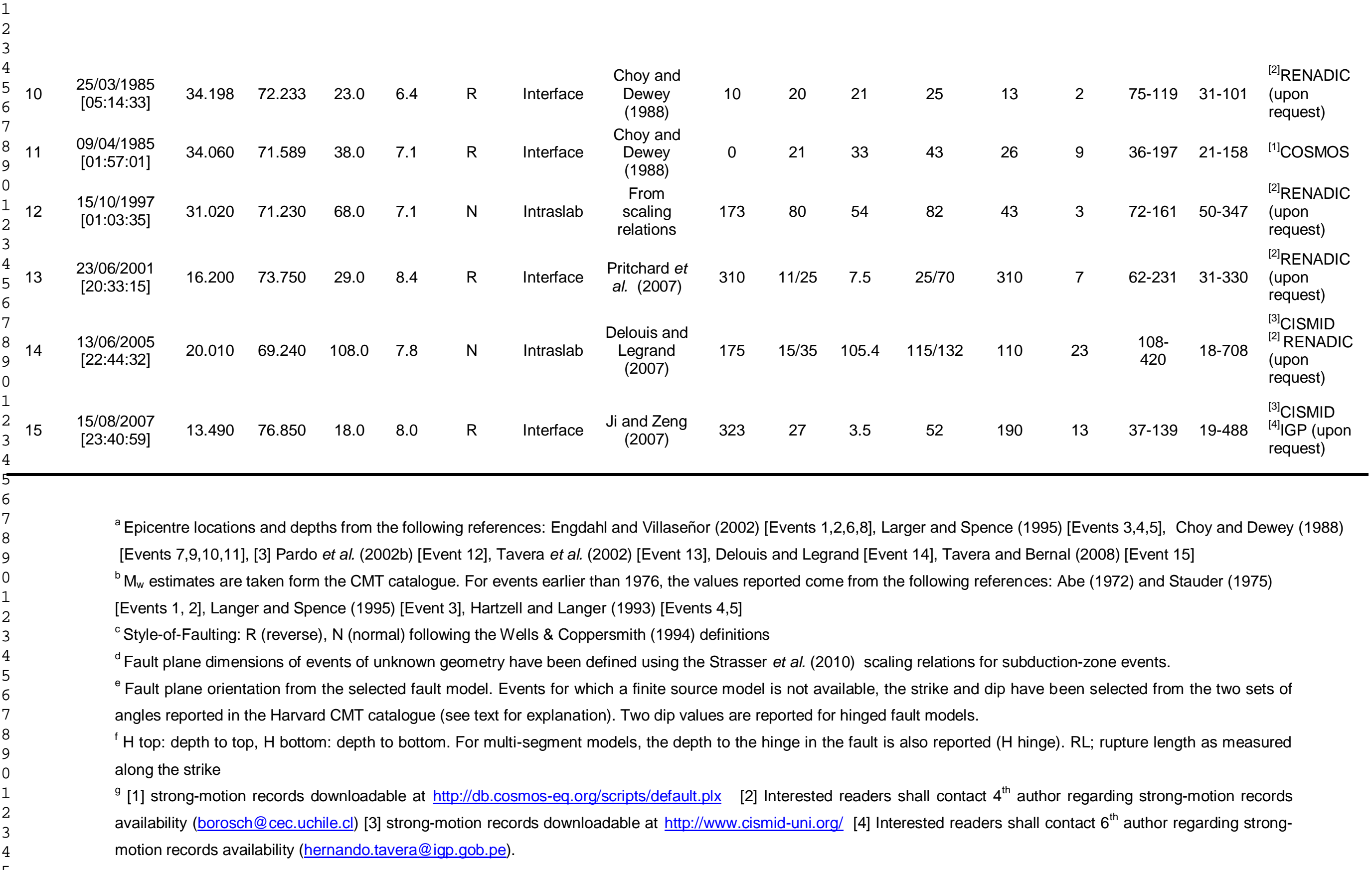


Table 2: Summary of characteristics of Chilean strong-motion stations used in this study.

\begin{tabular}{|c|c|c|c|c|c|c|c|c|c|c|c|c|c|c|c|c|c|}
\hline \multicolumn{6}{|c|}{ Instrument \& station information } & \multicolumn{8}{|c|}{ Geological \& geotechnical information } & \multicolumn{4}{|c|}{ Site classes assigned } \\
\hline Code $^{a}$ & Name & Lat [ㅇ] & $\begin{array}{l}\text { Lon } \\
{\left[{ }^{\circ} \mathrm{W}\right]}\end{array}$ & $\mathrm{IT}^{\mathrm{b}}$ & $\mathrm{IL}^{\mathrm{c}}$ & Surface geology ${ }^{d}$ & $\mathrm{SC}_{\mathrm{AB}}{ }^{\mathrm{e}}$ & $\mathrm{SC}_{\mathrm{CF}}{ }^{\dagger}$ & $\mathrm{SC}_{\mathrm{R}}{ }^{\mathrm{g}}$ & $V_{s 30}{ }^{h}$ & $\begin{array}{l}T_{0,}, \\
\text { LUP }\end{array}$ & $T_{0, C F}{ }^{j}$ & $\mathrm{~T}_{0, \mathrm{REC}}{ }^{\mathrm{k}}$ & $\mathrm{NH}^{\mathrm{m}}$ & $N Z^{n}$ & $J P^{\circ}$ & $\mathrm{CO}^{\mathrm{p}}$ \\
\hline $\begin{array}{l}\text { ACO } \\
{[\mathrm{REN}]}\end{array}$ & $\begin{array}{c}\text { Arica } \\
\text { Costanera }\end{array}$ & 18.474 & 70.313 & $\mathrm{~S}$ & B1 & $\begin{array}{l}\text { Marine and } \\
\text { continental } \\
\text { sediments on rock }{ }^{[1]} \\
\text {; Sediments }^{[2]} \\
\text { Marine and } \\
\text { continental } \\
\text { sediments on rock }^{[1]} \\
\text {; Sediments }^{[2]}\end{array}$ & - & $\mathrm{C}_{2}$ & - & $432^{[1]}$ & - & $\begin{array}{l}\mathrm{T}_{\mathrm{S} 1}=0.15 \\
\mathrm{~T}_{\mathrm{S} 2}=0.19\end{array}$ & $\begin{array}{c}0.33- \\
0.39\end{array}$ & C & C & II & II \\
\hline $\begin{array}{l}\text { ARIE } \\
{[D-D]}\end{array}$ & $\begin{array}{l}\text { Arica } \\
\text { Escuela }\end{array}$ & 18.494 & 70.312 & $E$ & B1 & $\begin{array}{l}\text { Volcanic rock } \\
\text { Rock }^{[1]}\end{array}$ & - & B & - & $1132^{[1]}$ & - & $\mathrm{T}_{\mathrm{S} 1}=0.11$ & 0.38 & B & B & 1 & I \\
\hline $\begin{array}{l}\text { CALA } \\
\text { [D-D] }\end{array}$ & $\begin{array}{l}\text { Calama } \\
\text { Hospital }\end{array}$ & 22.459 & 68.930 & $\mathrm{E}$ & B & $\begin{array}{l}\text { Sediments } \mathrm{s}^{[2]} \text {; Deep } \\
\text { sediments }^{[3]}\end{array}$ & - & - & - & - & - & - & $\sim 0.10$ & $\mathrm{C}$ & C & II & II \\
\hline $\begin{array}{l}\text { CAU } \\
\text { [REN] }\end{array}$ & Cauquenes & 35.97 & 72.32 & $S$ & B2 & 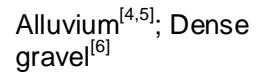 & $\mathrm{D}$ & - & II & $648^{[2]}$ & 0.45 & - & $\begin{array}{l}0.40- \\
0.62\end{array}$ & $C / D$ & C & III & II \\
\hline $\begin{array}{l}\text { CHIL } \\
{[\mathrm{REN}]}\end{array}$ & $\begin{array}{l}\text { Chillán- } \\
\text { Viejo }\end{array}$ & 36.60 & 72.10 & $S$ & B2 & $\begin{array}{l}\text { Alluvium } \\
\text { alluvium }^{[4]} ; \text { Soft } \\
\text { gravel }^{[6]} \text { Dense } \\
\text { Granite } \\
{[4, /] .}\end{array}$ & - & - & II & $568^{[2]}$ & 0.77 & - & $\begin{array}{l}0.35- \\
0.56\end{array}$ & $C / D$ & C & III & II \\
\hline $\begin{array}{l}\text { CONS } \\
{[\text { REN] }}\end{array}$ & Constitución & 35.33 & 72.41 & $S$ & B2 & $\begin{array}{l}\text { Paleozoic, } \\
\text { intrusive }{ }^{[5]} ; \text { Medium } \\
\text { density sand }^{[6]}\end{array}$ & $\mathrm{D}$ & - & III & $595^{[2]}$ & 0.83 & - & $\sim 0.74$ & $C / D$ & $\mathrm{D}$ & III & III \\
\hline $\begin{array}{l}\text { CUY } \\
\text { [REN] }\end{array}$ & Cuya & 19.160 & 70.177 & $S$ & $U$ & $\begin{array}{l}\text { Sedimentary rock } \\
\text { and marine } \\
\text { sediments }^{[1]}\end{array}$ & - & - & - & - & - & - & $\begin{array}{c}0.22- \\
0.33\end{array}$ & $\mathrm{C}$ & C & II & II \\
\hline $\begin{array}{l}\text { END } \\
\text { [REN] }\end{array}$ & $\begin{array}{l}\text { Santiago } \\
\text { Endesa }\end{array}$ & 33.45 & 70.65 & $P$ & B6 & $\begin{array}{l}\text { Firm gravel }\left.\right|^{[4]} \text {; } \\
\text { Alluvium }{ }^{[5]} \text {; Shallow } \\
\text { fill on dense gravel }{ }^{[8]}\end{array}$ & - & - & - & $513^{[3]}$ & 0.33 & - & $\begin{array}{l}0.70- \\
0.81\end{array}$ & C & C & III & II \\
\hline $\begin{array}{c}\text { HUA } \\
\text { [REN] }\end{array}$ & Hualañe & 34.97 & 71.82 & $S$ & B1 & $\begin{array}{l}\text { Alluviuum[ [4,7]; Dense } \\
\text { gravel }^{[6]}\end{array}$ & B & - & II & $527^{[2]}$ & 0.38 & - & $\sim 0.36$ & $C / D$ & C & II & II \\
\hline $\begin{array}{c}\text { ILLA } \\
\text { [REN] }\end{array}$ & Illapel & 31.63 & 71.17 & $S$ & B1 & $\begin{array}{l}\text { Alluvium }{ }^{[4,7]} \text {; Dense } \\
\text { gravel }^{[6]}\end{array}$ & $E$ & - & II & $613^{[2]}$ & 0.25 & - & $\begin{array}{l}0.16- \\
0.22\end{array}$ & C & C & II & II \\
\hline $\begin{array}{l}\text { ILO } \\
\text { [REN] }\end{array}$ & lloca & 34.93 & 72.18 & $S$ & B1 & Alluvium $^{[4,5,7]}$; Sand ${ }^{[6]}$ & $\mathrm{D}$ & - & II & $555^{[2]}$ & 0.33 & - & $\begin{array}{l}0.22- \\
0.43\end{array}$ & $C / D$ & C & II & II \\
\hline $\begin{array}{l}\text { IQU } \\
\text { [REN] }\end{array}$ & $\begin{array}{l}\text { Iquique- } \\
\text { Idiem }\end{array}$ & 20.215 & 70.140 & $S$ & B & Sediments $^{[2]}$ & - & - & - & - & - & - & $\sim 0.50$ & C & B & III & II \\
\hline
\end{tabular}




\begin{tabular}{|c|c|c|c|c|c|c|c|c|c|c|c|c|c|c|c|c|}
\hline $\begin{array}{l}\text { IQUC } \\
\text { [REN] }\end{array}$ & Iquique-Inp & 20.217 & 70.149 & $S$ & B & Sediments $^{[2]}$ & - & - & & - & - & - & $\sim 0.53$ & C & C & III \\
\hline $\begin{array}{l}\text { IQUI } \\
{[D-D]}\end{array}$ & $\begin{array}{l}\text { Iquique } \\
\text { Hospital }\end{array}$ & 20.214 & 70.138 & E & B & $\operatorname{Rock}^{[2]} ; \operatorname{Rock}^{[3]}$ & - & - & & - & - & - & $\sim 0.40$ & B & C & 1 \\
\hline $\begin{array}{l}\text { ISID } \\
\text { [REN] }\end{array}$ & San Isidro & 32.90 & 71.27 & $S$ & U & Alluvium $^{[1]}$ & D & - & & $789^{[2]}$ & 0.33 & - & 0.37 & C & C & II \\
\hline $\begin{array}{l}\text { LIG } \\
\text { [REN] }\end{array}$ & La Ligua & 32.45 & 71.25 & S & B1 & 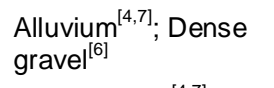 & D & - & II & $620^{[2]}$ & 0.29 & - & - & C & C & II \\
\hline $\begin{array}{l}\text { LLAY } \\
\text { [REN] }\end{array}$ & Llay Llay & 32.84 & 70.97 & S & B1 & $\begin{array}{l}\text { Soft alluvium }{ }^{[4,7]} \\
\text { Gravel and soft } \\
\text { lime }\end{array}$ & $\mathrm{E}$ & - & II & $610^{[2]}$ & 0.67 & - & $\sim 1.0$ & $\mathrm{D}$ & D & III \\
\hline $\begin{array}{l}\text { LLO } \\
\text { [REN] }\end{array}$ & Llolleo & 33.58 & 71.61 & $\mathrm{~S}$ & B1 & $\begin{array}{l}\text { Sandstone and } \\
\text { volcanic rock } k^{[4,7]} \\
\text { Dense sand } \\
\text { [6] }^{2}\end{array}$ & - & - & II & $305^{[2]}$ & 0.53 & - & $\begin{array}{l}0.42- \\
0.52\end{array}$ & $\mathrm{C} / \mathrm{D}$ & C & III \\
\hline $\begin{array}{l}\text { LOA } \\
\text { [REN] }\end{array}$ & El Loa & 22.636 & 68.152 & $\mathrm{~S}$ & U & Volcanic rock ${ }^{[1]}$ & - & - & - & - & - & - & $\sim 0.12$ & B & C & 1 \\
\hline $\begin{array}{l}\text { MEJI } \\
{[D-D]}\end{array}$ & $\begin{array}{l}\text { Mejillones - } \\
\text { Hospital }\end{array}$ & 23.103 & 70.446 & E & B & $\begin{array}{l}\text { Sediments }{ }^{[2]} ; \text { very } \\
\text { deep sands }^{[3]}\end{array}$ & - & - & - & - & - & - & $\begin{array}{l}0.33- \\
0.85\end{array}$ & C & D & III \\
\hline $\begin{array}{l}\text { MELP } \\
\text { [REN] }\end{array}$ & Melipilla & 33.68 & 71.22 & $S$ & B1 & $\begin{array}{l}\text { Alluvium } m^{[4]} ; \text { Dense } \\
\text { sand }^{[6]} ; \text { Granite }^{[7]}\end{array}$ & C & - & II & $724^{[2]}$ & 0.30 & - & $\begin{array}{l}0.20- \\
0.35\end{array}$ & C & C & II \\
\hline $\begin{array}{l}\text { PAP } \\
\text { [REN] }\end{array}$ & Papudo & 32.51 & 71.45 & $S$ & B1 & $\begin{array}{l}\text { Granite }^{[4,7]} ; \\
\text { Weathered rock }^{[6]}\end{array}$ & B & - & I & $517^{[2]}$ & 0.34 & - & $\begin{array}{l}0.26- \\
0.36\end{array}$ & $\mathrm{C} / \mathrm{D}$ & C & II \\
\hline $\begin{array}{l}\text { PICA } \\
{[D-D]}\end{array}$ & $\begin{array}{l}\text { Pica - } \\
\text { Hospital }\end{array}$ & 20.492 & 69.330 & $\mathrm{E}$ & B & Sediments $^{[2]}$ & - & - & - & - & - & - & $\sim 0.35$ & C & C & II \\
\hline $\begin{array}{l}\text { PICH } \\
\text { [REN] }\end{array}$ & Pichilemu & 34.38 & 72.02 & $S$ & B1 & $\begin{array}{l}\text { Slates, sandstone, } \\
\text { limestone }{ }^{[4,7]} ; \text { Rock }^{[6]}\end{array}$ & B & - & I & $623^{[2]}$ & 0.33 & - & $\sim 0.23$ & C & B & II \\
\hline $\begin{array}{l}\text { PIS } \\
\text { [REN] }\end{array}$ & Pisagua & 19.595 & 70.212 & $S$ & $U$ & $\begin{array}{l}\text { Shallow fill on } \\
\text { weathered rock }\end{array}$ & - & - & - & - & - & - & $\begin{array}{l}0.10- \\
0.33\end{array}$ & C & B & II \\
\hline $\begin{array}{l}\text { POCO1 } \\
\text { [REN] }\end{array}$ & $\begin{array}{c}\text { Poconchile } \\
1\end{array}$ & 18.456 & 70.067 & $S$ & B & $\begin{array}{l}\text { Marine and } \\
\text { continental } \\
\text { sediments on rock }{ }^{[1]}\end{array}$ & - & $\mathrm{C}_{2}$ & - & $511^{[1]}$ & - & $\begin{array}{l}\mathrm{T}_{\mathrm{s} 1}=0.24 \\
\mathrm{~T}_{\mathrm{s} 2}=0.22\end{array}$ & $\begin{array}{l}0.21- \\
0.57\end{array}$ & C & c & II \\
\hline $\begin{array}{l}\text { POCO2 } \\
\text { [D-D] }\end{array}$ & $\begin{array}{c}\text { Poconchile } \\
2\end{array}$ & 18.457 & 70.107 & $\mathrm{E}$ & B & $\begin{array}{l}\text { Marine and } \\
\text { continental } \\
\text { sediments on rock }\end{array}$ & - & $\mathrm{C}_{2}$ & - & - & - & $\begin{array}{l}\mathrm{T}_{\mathrm{s} 1}=0.24 \\
\mathrm{~T}_{\mathrm{s} 2}=0.22\end{array}$ & 0.21 & C & C & II \\
\hline $\begin{array}{c}\text { PU } \\
\text { [REN] }\end{array}$ & Putre & 18.197 & 69.574 & $S$ & U & Weathered rock ${ }^{[3]}$ & - & - & - & - & - & - & $\begin{array}{l}0.38- \\
0.56\end{array}$ & C & B & III \\
\hline $\begin{array}{r}\text { QUIN } \\
\text { [REN] }\end{array}$ & Quintay & 33.20 & 71.68 & $\mathrm{~S}$ & S & $\begin{array}{l}\text { Paleozoic } \\
\text { intrusives }^{[5]} \text {; Rock }\end{array}$ & - & - & I & $595^{[2]}$ & 0.50 & - & $\begin{array}{l}0.48- \\
0.66\end{array}$ & C & B & II \\
\hline $\begin{array}{c}\text { RAP } \\
\text { [REN] }\end{array}$ & Rapel & 34.03 & 71.58 & $\mathrm{R}$ & $\mathrm{T}$ & $\begin{array}{l}\text { Sediments }{ }^{[4, /]} \\
\text { Paleozoic } \\
\text { intrusives }\left[{ }^{[5]} ; \text { Rock }^{[6]}\right.\end{array}$ & B & - & I & $3010^{[2]}$ & 0.40 & - & $\begin{array}{l}0.10- \\
0.29\end{array}$ & A & A & 1 \\
\hline $\begin{array}{l}\text { SANT } \\
\text { [REN] }\end{array}$ & Santiago & 33.47 & 70.67 & $S$ & B3 & $\begin{array}{l}\text { Firm gravel }\left.\right|^{[4]} \\
\text { Alluvium }^{[5]}\end{array}$ & - & - & & - & 0.65 & - & $\begin{array}{l}0.66- \\
0.91\end{array}$ & C & C & III \\
\hline
\end{tabular}




\begin{tabular}{|c|c|c|c|c|c|c|c|c|c|c|c|c|c|c|c|c|c|}
\hline $\begin{array}{l}\text { SFDO } \\
\text { [REN] }\end{array}$ & $\begin{array}{l}\text { San } \\
\text { Fernando }\end{array}$ & 34.60 & 71.00 & S & B1 & 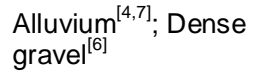 & D & - & II & $543^{[2]}$ & 0.36 & - & $\begin{array}{l}0.22- \\
0.46\end{array}$ & C & C & II & II \\
\hline $\begin{array}{l}\text { SFEL } \\
\text { [REN] }\end{array}$ & San Felipe & 32.75 & 70.73 & S & B1 & $\begin{array}{l}\text { Alluvium } \\
\text { gravel }^{[6]}{ }^{[4,7]} ; \text { Dense }\end{array}$ & D & - & II & $502^{[2]}$ & 0.50 & - & $\sim 0.12$ & C & C & II & II \\
\hline $\begin{array}{c}\text { TAL } \\
\text { [REN] }\end{array}$ & Talca & 35.43 & 71.67 & S & B1 & $\begin{array}{l}\text { Alluvium }{ }^{[4,7]} \text {; Dense } \\
\text { gravel }^{[6]}\end{array}$ & $\mathrm{E}$ & - & II & $598^{[2]}$ & 0.83 & - & 0.17 & C & C & II & IIII \\
\hline $\begin{array}{l}\text { TCP } \\
{[D-D]}\end{array}$ & Tocopilla & 22.104 & 70.214 & $\mathrm{E}$ & $U$ & $\operatorname{Rock}^{[2]}$ & - & - & - & - & - & - & $\sim 0.10$ & B & B & I & I \\
\hline $\begin{array}{l}\text { UTFSM } \\
\text { [REN] }\end{array}$ & $\begin{array}{l}\text { Valparaiso } \\
\text { UTFSM }\end{array}$ & 33.03 & 71.60 & S & B1 & $\begin{array}{l}\text { Volcanic rock } \\
\text { Rock }^{[6]}\end{array}$ & B & - & I & $1421^{[2]}$ & 1.00 & - & $\begin{array}{l}0.78- \\
0.87\end{array}$ & A & A & I & 1 \\
\hline $\begin{array}{l}\text { VALMD } \\
\text { [REN] }\end{array}$ & $\begin{array}{l}\text { Valparaiso } \\
\text { El } \\
\text { Almendral }\end{array}$ & 33.03 & 71.64 & S & $\mathrm{R}$ & $\begin{array}{l}\text { Fill }^{[4,6]} \text {; Soil } \\
\text { Artificial fill }\end{array}$ & D & - & III & $360^{[3]}$ & 0.67 & - & - & D & D & III & III \\
\hline $\begin{array}{l}\text { VENT } \\
\text { [REN] }\end{array}$ & Ventanas & 33.03 & 71.62 & S & B6 & $\begin{array}{l}\text { Loose sand }{ }^{[4]} ; \\
\text { Alluvium }^{[5]} ; \text { Sand } \\
{[6,7]}\end{array}$ & D & - & III & $331^{[2]}$ & 0.67 & - & $\begin{array}{c}0.76- \\
1.0\end{array}$ & D & D & III & III \\
\hline $\begin{array}{c}\text { VIL } \\
{[R E N]}\end{array}$ & Los Vilos & 31.92 & 71.50 & $S$ & B1 & $\begin{array}{l}\text { Sedimentary } \\
\text { rock }^{[4,7]} ; \text { Rock }^{[6]}\end{array}$ & B & - & I & $1215^{[2]}$ & - & - & 0.26 & A & B & I & I \\
\hline $\begin{array}{l}\text { VMAR } \\
\text { [REN] }\end{array}$ & $\begin{array}{l}\text { Viña del } \\
\text { Mar }\end{array}$ & 33.02 & 71.55 & S & B10 & $\begin{array}{l}\text { Alluvium and sand }{ }^{[4]} \\
\text { Sand }^{[6]}\end{array}$ & - & - & III & $273^{[3]}$ & 0.50 & - & $\begin{array}{l}0.50- \\
0.80\end{array}$ & D & D & III & 1 \\
\hline $\begin{array}{l}\text { ZAP } \\
{[\text { REN] }}\end{array}$ & Zapallar & 32.55 & 71.46 & S & B1 & Rock $^{[6]} ;$ Granite $^{[7]}$ & B & - & I & $605^{[2]}$ & 0.41 & - & $\sim 0.18$ & C & B & II & II \\
\hline
\end{tabular}

${ }^{a}$ Station code, followed by the network: REN=RENADIC; D-D=DGC-DIC.

${ }^{b}$ Instrument type: E=ETNA; P=PK-130; R=RFT-250; $S=S M A-1$;

${ }^{c}$ Instrument location: $\mathrm{B}=$ building, followed by number of storeys if known; $\mathrm{S}=$ shelter; $\mathrm{T}=$ =tunnel; $\mathrm{U}=$ unknown.

${ }^{d}$ Description of the surface geology, based on the following references: [1] Geologic map of Chile (SNGM, 1982); [2] Alva Hurtado (2005); [3] this study; [4] Çelebi (1988); [5] Campbell et al. (1990); [6] Riddell (1995); [7] EERI reconnaissance report (1986); [8] Midorikawa et al. (1991) and Midorikawa (1992).

NEHRP site classes assigned by Atkinson \& Boore $(2003,2008)$.

${ }^{\dagger}$ Site classes assigned by Cortez-Flores (2004) following the Rodriguez-Marek et al. (2001) site classification scheme: $\mathrm{B}=$ Rock; $\mathrm{C}_{2}=\mathrm{Shallow}$ stiff soil.

${ }^{9}$ Soil classes assigned by Riddell (1995) following the 1993 Chilean seismic design code provisions

${ }^{\mathrm{h}}$ Average shear-wave velocity over the top $30 \mathrm{~m}$, in $\mathrm{m} / \mathrm{s}$, determined from: [1] Vs profiles obtained by Cortez-Flores (2004) using SASW; [2] V $\mathrm{V}_{\mathrm{S}}$ profiles determined by Araneda \& Saragoni (1994); $\mathrm{V}_{\mathrm{S}}$ profiles obtained by Midorikawa et al. (1991) and Midorikawa (1992). For calculation purposes, when $V_{S}$ data were available at depths $<30 \mathrm{~m}$, the $V_{S}$ value of the last layer was assumed constant to $30 \mathrm{~m}$ depth.

i Predominant site period, in seconds, determined by Luppichini (2004). Values listed as reported by Ruiz \& Saragoni (2005).

${ }^{\mathrm{j}}$ Predominant site period determined by Cortez-Flores (2004). Ts was estimated as the period corresponding to the maximum ratio of response spectra at the surface over the response spectra of outcrop input motion and $\mathrm{T}_{\mathrm{S} 2}$ corresponds to the characteristic site period calculated from the equation $\mathrm{T}_{\mathrm{S}}=4 \mathrm{H} / \mathrm{V}_{\mathrm{S}}$.

Predominant site period calculated from accelerogram by considering the $\mathrm{H} / \mathrm{V}$ ratio of the response spectra, following the approach of Zhao et al. (2006a). The lower and upper boundaries of the interval reported correspond to the maximum and minimum values of the natural site period found when using multiple records from the same station. Values are only listed for those records whose vertical component is available

'Average shear-wave velocity over the top $30 \mathrm{~m}$, in $\mathrm{m} / \mathrm{s}$, used in analyses.

${ }^{m}$ Site class according to the NEHRP (1997) provisions used in analyses.

${ }^{n}$ Site class assigned following the New Zealand site classification, which is based on surface geology, geotechnical properties, natural site period and depth to bedrock (see McVerry et al. (2006) for details)

${ }^{\circ}$ Site class assigned following the Zhao et al. (2006b) scheme, considering the natural period of the site

${ }^{\mathrm{p}}$ Site class assigned to compute the design loads prescribed by the 1996 Chilean seismic code 
Table 3. Information on Peruvian strong-motion stations used in this study.

\begin{tabular}{|c|c|c|c|c|c|c|c|c|c|c|c|c|c|c|}
\hline Code & Name & IT & $\begin{array}{l}\text { Lat } \\
{\left[\because{ }^{\circ}\right]}\end{array}$ & 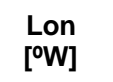 & Loc & Surface geology ${ }^{a}$ & $\mathrm{SC}_{\mathrm{RM}}$ & $\begin{array}{l}\mathrm{V}_{\mathrm{S} 30} \\
{[\mathrm{~m} / \mathrm{s}]}\end{array}$ & $\begin{array}{l}\mathrm{T}_{0} \\
\mathrm{CF}\end{array}$ & $\mathrm{T}_{0}$, cls & $\mathbf{T}_{0, \mathrm{REC}}$ & $\mathrm{NH}$ & NZ & JP \\
\hline $\begin{array}{l}\text { ANC } \\
{[\text { IGP] }}\end{array}$ & Ancon & $\mathrm{D}$ & 11.776 & 77.150 & U & Alluvial gravel (soil) ${ }^{[2]}$ & $\mathrm{s}$ & $280^{[5]}$ & & $0.2-0.3$ & $\begin{array}{l}0.30 \\
0.10\end{array}$ & $C / D$ & C & II \\
\hline $\begin{array}{c}\text { ANR } \\
\text { [CER] }\end{array}$ & $\begin{array}{l}\text { Asamblea } \\
\text { Nacional de } \\
\text { Rectores }\end{array}$ & $\mathrm{D}$ & 12.123 & 76.976 & B & Alluvial gravel (soil) ${ }^{[2]}$ & $F G$ & $205^{[5]}$ & & $0.2-0.3$ & $\begin{array}{l}0.50 \\
0.15\end{array}$ & D & C & II \\
\hline $\begin{array}{l}\text { CAL } \\
{[\mathrm{CIS}]}\end{array}$ & Callao & $E$ & 12.060 & 77.150 & S & $\begin{array}{l}\text { Soft soil }{ }^{[1]} ; \text { Soft clay }{ }^{[2]} ; \text { Granular } \\
\text { fill over fine stratified soils }{ }^{[3]}\end{array}$ & S & $75^{[5]}$ & & $0.5-0.6$ & $\begin{array}{l}0.53 \\
0.52\end{array}$ & $\mathrm{D} / \mathrm{E}$ & $\mathrm{E}$ & IV \\
\hline $\begin{array}{l}\text { CDL- } \\
\text { CIP } \\
{[\text { CIS] }}\end{array}$ & CDL-CIP & $E$ & 12.092 & 77.049 & $S$ & $\begin{array}{l}\text { Dense, stiff gravel deposit (Lima } \\
\text { Conglomerate })^{[1]} \text {; Alluvial gravel } \\
\text { (soil) }{ }^{[2]}\end{array}$ & $\mathrm{FG}$ & & & $0.1-0.2$ & $\begin{array}{l}0.82 \\
0.30\end{array}$ & D & C & III \\
\hline $\begin{array}{c}\text { CER } \\
\text { [CER] }\end{array}$ & Ceresis & $E$ & 12.103 & 76.998 & U & Alluvial gravel (soil) ${ }^{[2]}$ & $\mathrm{FG}$ & & & $0.1-0.2$ & $\begin{array}{l}0.28 \\
0.45\end{array}$ & D & C & III \\
\hline $\begin{array}{l}\text { CSM } \\
\text { [CIS] }\end{array}$ & Cismid & $\mathrm{D}$ & 12.013 & 77.050 & B1 & $\begin{array}{l}\text { Dense, stiff gravel deposit (Lima } \\
\text { Conglomerate })^{[1]} \text {; Alluvial gravel } \\
\text { (soil) }{ }^{[2]}\end{array}$ & $\mathrm{FG}$ & $184^{[5]}$ & & $0.2-0.3$ & $\begin{array}{l}0.05 \\
0.10\end{array}$ & C & C & II \\
\hline $\begin{array}{l}\text { GEO } \\
{[\text { IGP] }}\end{array}$ & $\begin{array}{l}\text { Geological } \\
\text { Institute }\end{array}$ & A & 12.08 & 76.95 & $U$ & Coarse dense gravel & & & & & - & C & B & II \\
\hline $\begin{array}{l}\text { HUA } \\
{[\text { IGP] }}\end{array}$ & $\begin{array}{l}\text { Casa Huaco - } \\
\text { Las Gardenias }\end{array}$ & A & 12.13 & 76.98 & $U$ & Alluvial deposits & & & & & - & C & $\mathrm{B}$ & II \\
\hline $\begin{array}{l}\text { ICA2 } \\
{[\mathrm{CIS}]}\end{array}$ & Ica 2 & A & 14.089 & 75.732 & B & Silty sand, soil ${ }^{[1]}$ & $S$ & 312 & & - & $\begin{array}{l}0.72 \\
0.48\end{array}$ & D & C & III \\
\hline $\begin{array}{l}\text { LMOL } \\
{[\mathrm{IGP}]}\end{array}$ & $\begin{array}{l}\text { La Molina } \\
\text { Universidad } \\
\quad \text { Agraria }\end{array}$ & A & 12.085 & 76.948 & U & $\begin{array}{l}\text { Alluvial deposits (soft clays and } \\
\text { sand) }{ }^{[4]}\end{array}$ & & & & & & & & \\
\hline $\begin{array}{l}\text { MAY } \\
{[\text { IGP] }}\end{array}$ & Mayorazgo & $\mathrm{D}$ & 12.055 & 76.944 & $U$ & Sand and silt ${ }^{[2]}$ & $S$ & $276^{[5]}$ & & $0.2-0.3$ & $\begin{array}{l}0.22 \\
0.20\end{array}$ & C & C & II \\
\hline $\begin{array}{l}\text { MOL } \\
{[\mathrm{CIS}]}\end{array}$ & Molina & $E$ & 12.10 & 76.89 & B & $\begin{array}{l}\text { Shallow soil overlying dense } \\
\text { Lima Conglomerate; Sand }{ }^{[2]}\end{array}$ & $\mathrm{R}$ & $380^{[5]}$ & & $0.2-0.4$ & $\begin{array}{l}0.13 \\
0.20\end{array}$ & C & C & II \\
\hline $\begin{array}{l}\text { MOQ1 } \\
{[\mathrm{CIS}]}\end{array}$ & Moquega 1 & A & 17.187 & 70.929 & S & $\begin{array}{l}\text { Alluvial deposits (sandy } \\
\text { gravels) } \text { (5] }^{[5]}\end{array}$ & & 573 & & & $\begin{array}{l}0.11- \\
0.18\end{array}$ & C & B & II \\
\hline $\begin{array}{l}\text { NNA } \\
{[\text { IGP] }}\end{array}$ & Ñaña & D & 11.987 & 76.389 & $U$ & $\operatorname{Rock}^{[2]}$ & $\mathrm{R}$ & - & & & $\begin{array}{l}0.10 \\
0.22\end{array}$ & B & B & 1 \\
\hline $\begin{array}{l}\text { PCN } \\
{[\text { IGP] }}\end{array}$ & Parcona & $\mathrm{D}$ & 14.042 & 75.699 & U & Soil ${ }^{[1]}$ & $S$ & 456 & & & $\begin{array}{l}0.42 \\
0.54\end{array}$ & $C / D$ & C & III \\
\hline $\begin{array}{l}\text { PUCP } \\
{[\text { PUCP] }}\end{array}$ & $\begin{array}{l}\text { Universidad } \\
\text { Catolica del Peru }\end{array}$ & $\mathrm{D}$ & 12.074 & 77.080 & B & Alluvial gravel (soil) ${ }^{[2]}$ & $\mathrm{FG}$ & $125^{[5]}$ & & $0.2-0.3$ & $\begin{array}{l}0.90 \\
0.90\end{array}$ & D & D & III \\
\hline $\begin{array}{c}\text { RIN } \\
{[\text { CER] }}\end{array}$ & Rinconada & $\mathrm{D}$ & 12.084 & 76.921 & $U$ & $\begin{array}{l}\text { Fill consisting of sand, silt and } \\
\text { grave }^{[2]}\end{array}$ & $S$ & $200^{[5]}$ & & $0.2-0.3$ & 0.32 & $C / D$ & C & II \\
\hline
\end{tabular}


a Description of surface geology profile, based on the following references: [1] EERI (2007) [2] Bernal and Tavera (2007a,b) [3] information provided by the strong-motion network in the accelerogram heading [4]Espinosa et al. (1977) [5] Cortez-Flores (2004)

${ }^{\mathrm{b}}$ Site class assigned by Rodriguez-Marek et al. (2007).

${ }^{c}$ Average shear-wave velocity over the top $30 \mathrm{~m}$. For the Ica stations, this is based on the $\mathrm{V}_{\mathrm{s}}$ profiles obtained by Rosenblad and Bay (2008) using SASW. For the Lima stations, the value tabulated is a tentative estimate of $\mathrm{V}_{\mathrm{S}, 30}$ based on the $\mathrm{V}_{\mathrm{s}}$ profile inferred by Bernal and Tavera (2007a,b) using an infinite flat-layered half-space model.

Natural site period $\left(\mathrm{T}_{0}\right)$ inferred from the microzonation map of Lima (Aguilar Bardales and Alva Hurtado, 2007). Values are not available for the NNA station in Lima, nor for the Ica stations. while the bottom value corresponds to the north-south component.

${ }^{\mathrm{f}}$ Site class according to the NEHRP (1997) provisions. The number in brackets corresponds to the $\mathrm{V}_{\mathrm{S}(30)}$ value assumed when explicitly required, following the recommendations of Atkinson and Boore (2003).

${ }^{\mathrm{g}}$ Site class according to the New Zealand site classification, which is based on surface geology, geotechnical properties and depth to bedrock. See McVerry et al. (2006) for details.

${ }^{\mathrm{h}}$ Site class according to the Zhao et al. (2006a) scheme, considering $\mathrm{V}_{\mathrm{S} 30}$ and the natural period of the site.

${ }^{\mathrm{i}}$ Site class assumed to compute the design loads prescribed by the 1977 and 2003 Peruvian seismic codes. 

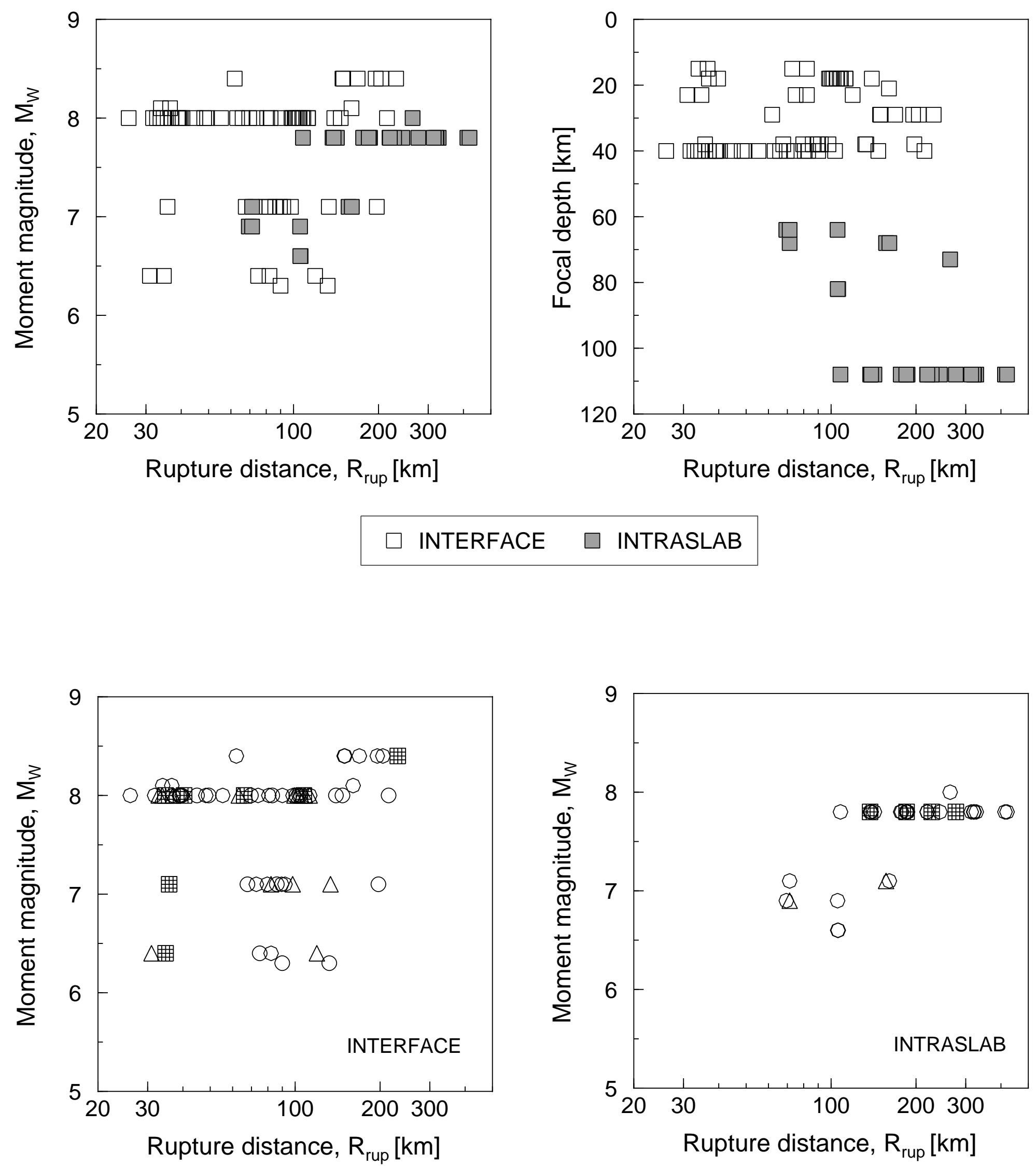

䧃 NEHRP A\&B $\bigcirc$ NEHRP C\&C/D $\triangle$ NEHRP D\&D/E 